Louisiana State University

LSU Digital Commons

1969

\title{
Sand Movement in Relation to Beach Topography.
}

David Samuel Mcarthur

Louisiana State University and Agricultural \& Mechanical College

Follow this and additional works at: https://digitalcommons.Isu.edu/gradschool_disstheses

\section{Recommended Citation}

Mcarthur, David Samuel, "Sand Movement in Relation to Beach Topography." (1969). LSU Historical Dissertations and Theses. 1555.

https://digitalcommons.Isu.edu/gradschool_disstheses/1555

This Dissertation is brought to you for free and open access by the Graduate School at LSU Digital Commons. It has been accepted for inclusion in LSU Historical Dissertations and Theses by an authorized administrator of LSU Digital Commons. For more information, please contact gradetd@lsu.edu. 
This diesertation has boon microfilmed exactly as recolved

$69-17,119$

McARTHUR, David Samuel, 1941SAND MOVEMENT IN RELATION TO BEACH TOPOGRAPHY.

Louisiana State University and Agricultural and Mechanical College, Ph.D., 1969 Geography

University Microfilms, Inc., Ann Årbor, Michigan 


\section{A Dissertation}

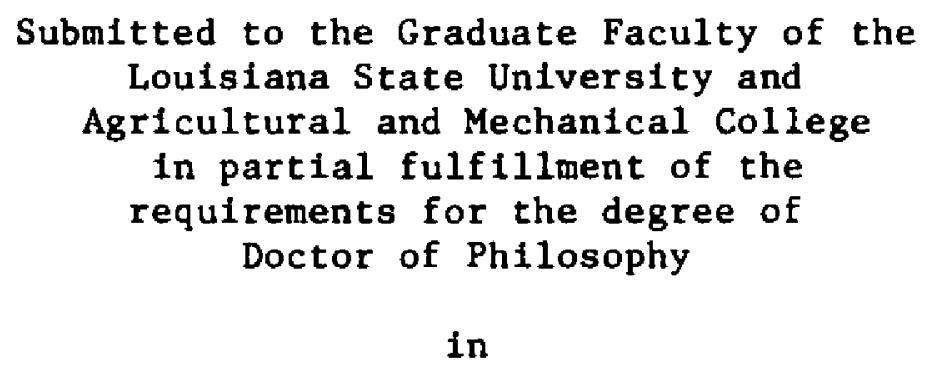

The Department of Geography and Anthropology

by

David Samuel McArthur

B.Sc., University of New Zealand, 1962

M.Sc. (Hons.), University of Canterbury, 1964

January, 1969 


\section{SAND MOVEMENT IN RELATION TO BEACH TOPOGRAPHY}

By David Samue1. McArthur

\section{ACKNOWLEDGMENT}

Research in the zone of breaking waves is at times both difficult and tiring. During collection of the present data set, cold water and a very demanding schedule were additional hardships. It is therefore with gratitude that the writer acknowledges fleld assistance by Evans Waddell and Norwood H. Rector. Their contributions in this respect were always generous. E. Waddell also assisted with gathering of preliminary data on which planning of the reported research was based, and $N$. Rector spent many a long day designing and producing equipment necessary for field work. The assistance of these persons was obviously vital to the success of the program.

Work was sponsored by Coastal Studies Institute under contract to the Geography Branch, Offlce of Naval Research, Project No. Nonr 1575(03), Task Order No. NR 388002 . Encouragement and advice from Dr. William G. McIntire, under whose direction the program was conducted, always was appreciated and followed to advantage.

Storage and docking facilities on Hurricane Island, as well as numerous miscellaneous services, were willingly supplied by $\mathrm{Mr}$. L. Gammon of Panama C1ty. His assistance is gratefully acknowledged. 
TABLE OF CONTENTS

Acknowledgment . . . . . . . . . . . . . . . . . . . . . 1

Tables............................ . . 111

Figures. . . . . . . . . . . . . . . . . . . . . 1v

Abstract . . . . . . . . . . . . . . . . . . . . v

Introduction . . . . . . . . . . . . . . . . . . . . 1

Data Collection and Reduction. . . . . . . . . . . . . . 4

Beach Characteristics. . . . . . . . . . . . . . 4

Tracer Production, Release, and Sampling . . . . . . . 4

Mapplng Tracer Distributions . . . . . . . . . . . . 12

Measurement of Waves and Currents. . . . . . . . . . 13

Tracer Dispersion. . . . . . . . . . . . . . . . . . 18

Median Paths of Tracer Motion. . . . . . . . . . . . 18

Tracer Released in the Swash Zone... . . . . . . 18

Tracer Released in the Trough . . . . . . . . . 18

Tracer Released on the Bar. . . . . . . . . . . . 21

Tracer Dispersion and Beach-Process Variables. . . . . . 22

Swash Zone. . . . . . . . . . . . . . . . . . . 22

Trough and Bar Zones. . . . . . . . . . . . . . 23

Summary and Conclusions. . . . . . . . . . . . . . . 27

Blbliography . . . . . . . . . . . . . . . . . 36 


\section{LIST OF TABLES}

Table

I. Summary of Paired Student's " $T$ " Tests Between

S1ze Statistics of Tagged and Untagged Sand. . . . . . 8

II. Summary of Analysis of Vartance on Sample

Replications Around Sampling Stations. . . . . . . 8

III. Summary of Chi-Square Test on Grain Count

Replication. . . . . . . . . . . . . . . 11

IV. Summary Wave Stat1stics. . . . . . . . . . . 16 
1. Beach terminology . . . . . . . . . . . . . . 3

2. Location of research. . . . . . . . . . . . . 3

3. Contour maps of beach topography. . . . . . . . . . 5

4. Site of experiment 1. . . . . . . . . . . . 6

5. Site of experiments 2 and 3............. 6

6. Field plans..................... 9

7. Collection and reduction of wave records. . . . . . 15

8. Trough current distributions. . . . . . . . . . 17

9. Crest positions of tracer concentration surfaces. . 19

$10 \mathrm{a}-\mathrm{b}$. Tracer dispersion, experiment 1. . . . . 29-30

11 a-d. Tracer dispersion, experiment 2 . . . . . . 31-34

12. Tracer dispersion, experiment 3.......... 35 


\begin{abstract}
Tracer experiments were conducted on the Gulf Coast beach of Hurricane Island, Florida, to obtain information on sediment transfer between foreshore, trough, and bar topography. Concurrent measurements of waves and currents were collected. Alongshore transport of tracer released in the three topographic zones was greater than normal-to-shore movement, even when the angle between wave crests and the shoreline was small. Seaward movement of tracer placed in the trough and bar zones took place during alongshore transport only when waves broke on the bar, and was most marked when wave steepness had a value near 0.04 . During these conditions tracer released in the trough moved onto and along the bar crest. At other times landward displacement of bar and trough tracer accompanied alongshore transport. Tracer placed on the bar moved into the trough.

Only when a subaqueous shoal replaced the trough immediately seaward of the beach step did appreciable amounts of tracer move seaward from the foreshore. Rhythmic topography appears therefore to provide an 1mportant mechanism for onshore-offshore movement of sediment within a beach system. Transport of tracer from the trough and bar onto the foreshore was negligible orer all experiments.
\end{abstract}




\section{INTRODUCTION}

The cyclic nature of beach change (Shepard, 1950; Inman and Fł1loux, 1960; Strahler, 1966) suggests a complementary interaction between adjacent or nearby beach zones. Erosion at one location is balanced by accretion at another. A prevalent concept is that the most landward bar* is the sediment source during foreshore accretion and provides for sediment storage during foreshore erosion (Shepard, 1963, p. 179). The concept, consistent with wave-tank derived models of nearshore sediment circulation (Scott, 1954; Rector, 1954), emphasizes sediment movement normal to the shoreline. Numerous field studies over the past decade have alternatively shown that the main directional component of beach sediment movement is alongshore (Medvedev and Albulatov, 1958; Davidsson, 1958; Wright, 1962; Sato, 1962; and Ingle, 1966). It is apparent that sediment transfer between beach zones (onshore-offshore movement) takes place within a circulation of sediment which possesses a significant alongshore component.

Short-term sediment transfer between topographically defined beach zones was the subject of research presented in this report. In each of three experiments tracer was released simultaneously on the swash slope, trough bottom, and bar crest (F1gure 1), and subsequent dispersion over small beach sections was mapped for a series of time lags from trace: Input. Measurements of waves and currents

*Terminology used throughout the report follows definitions of Wiege1 (1953). 
were collected during tracer experiments to enable relationships between dispersion and sea conditions to be established.

Research was conducted on the Gulf Coast beach of Hurricane (or She11) Island seaward of Panama C1ty, Florida, during October of 1967 (Figure 2). 


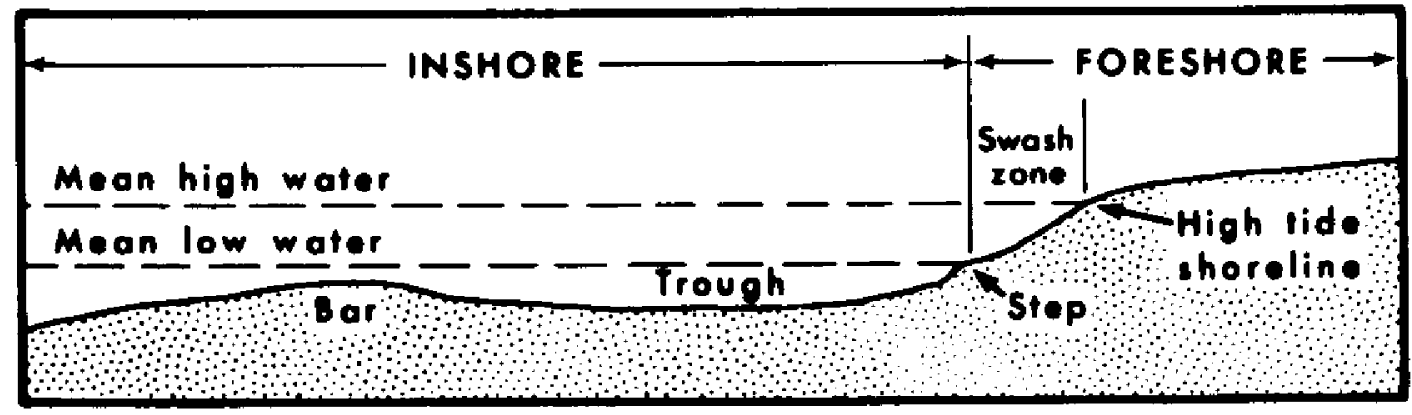

Figure 1. Beach terminology.

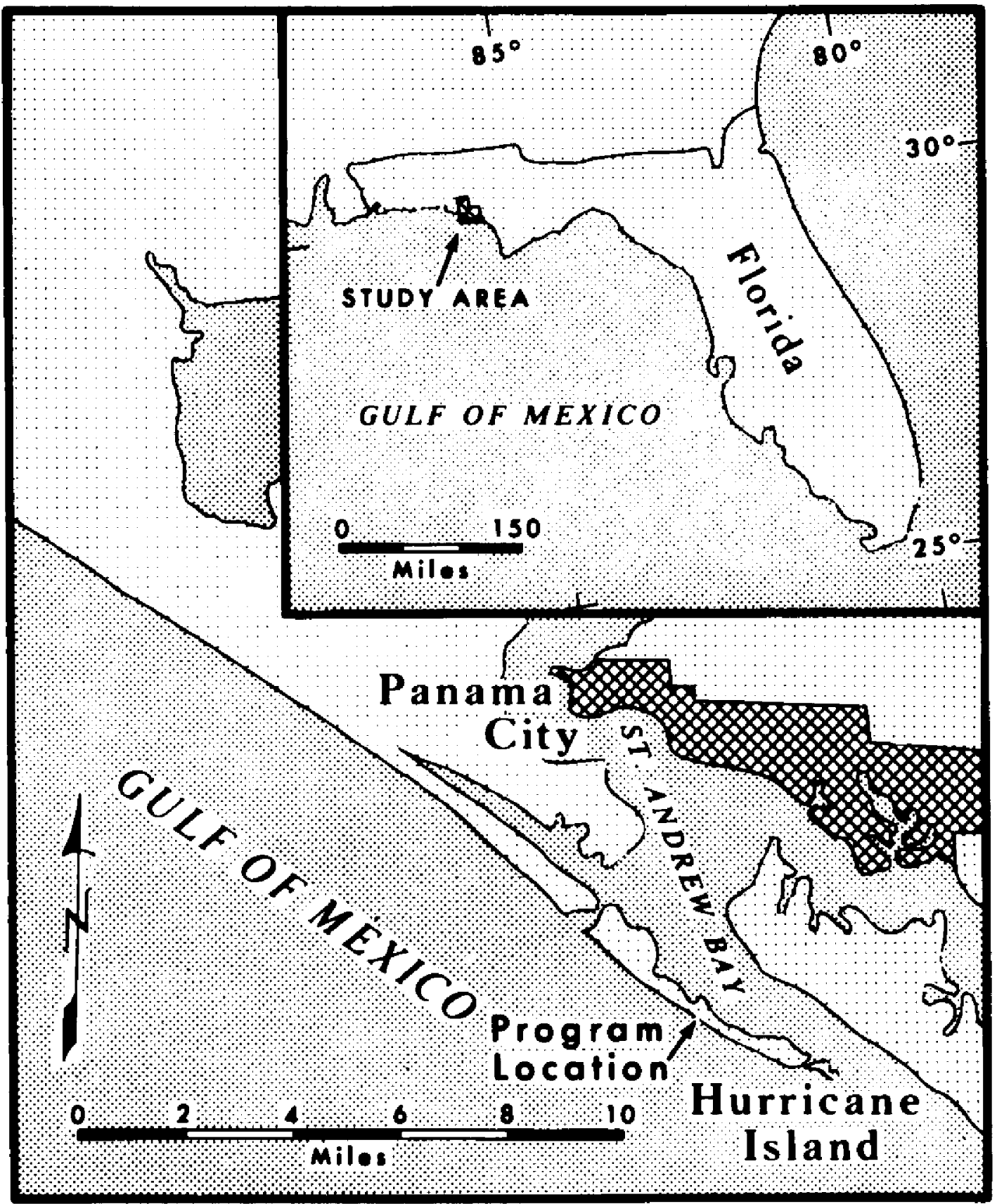

Figure 2. Location of research. 


\section{DATA COLLECTION AND REDUCTION}

\section{BEACH CHARACTERISTICS}

Data were collected over two beach areas, each measuring 500 feet alongshore by approximately 200 feet offshore. Both sites extended from landward of the high-tide shoreline to seaward of the Inner-bar crest. The contour maps of Figure 3 represent beach relief at the beginning of each experiment.

The two beach sections studied were quite different with respect to topography. Trough and bar were continuous alongshore at the site of experiments 2 and 3 , and the shoreline was relatively strafght (Figure 5). At the location of experiment 1 , however, the bar coalesced with the swash zone at the northwestern end of the test site, glving rise to a gently sloping offshore profile, herein termed a "shoal." The discontinuous trough and bar were posttioned seaward of a shoreline embayment (Figure 4).

TRACER PRODUCTION, RELEASE, AND SAMPLING

Tracer was prepared by tagging sand grains with a fluorescent coating. The following mfxture, based on work by Yasso (1965), gave good results:

\begin{tabular}{|c|c|c|c|c|}
\hline $\begin{array}{l}\text { Acrylic lacquer paint } \\
\text { Toluene }\end{array}$ & $\begin{array}{l}100 \\
100\end{array}$ & $\begin{array}{l}\text { gms. } \\
\text { gms. }\end{array}$ & 400 gms. - & \\
\hline $\begin{array}{l}\text { Vinyl plastic } \\
\text { Toluene } \\
\text { Ketone }\end{array}$ & $\begin{array}{r}22.5 \\
140.0 \\
37.5\end{array}$ & $\begin{array}{l}\text { gms . - } \\
\text { gms. . } \\
\text { gms. - - }\end{array}$ & & Tracer \\
\hline Sand (dry) & 5,000 & gms & & \\
\hline
\end{tabular}

Actual tagging of dried sand was accomplished by tumbling tracer components in a cement mixer.

A most desirable property of tracer is that its behavior within 


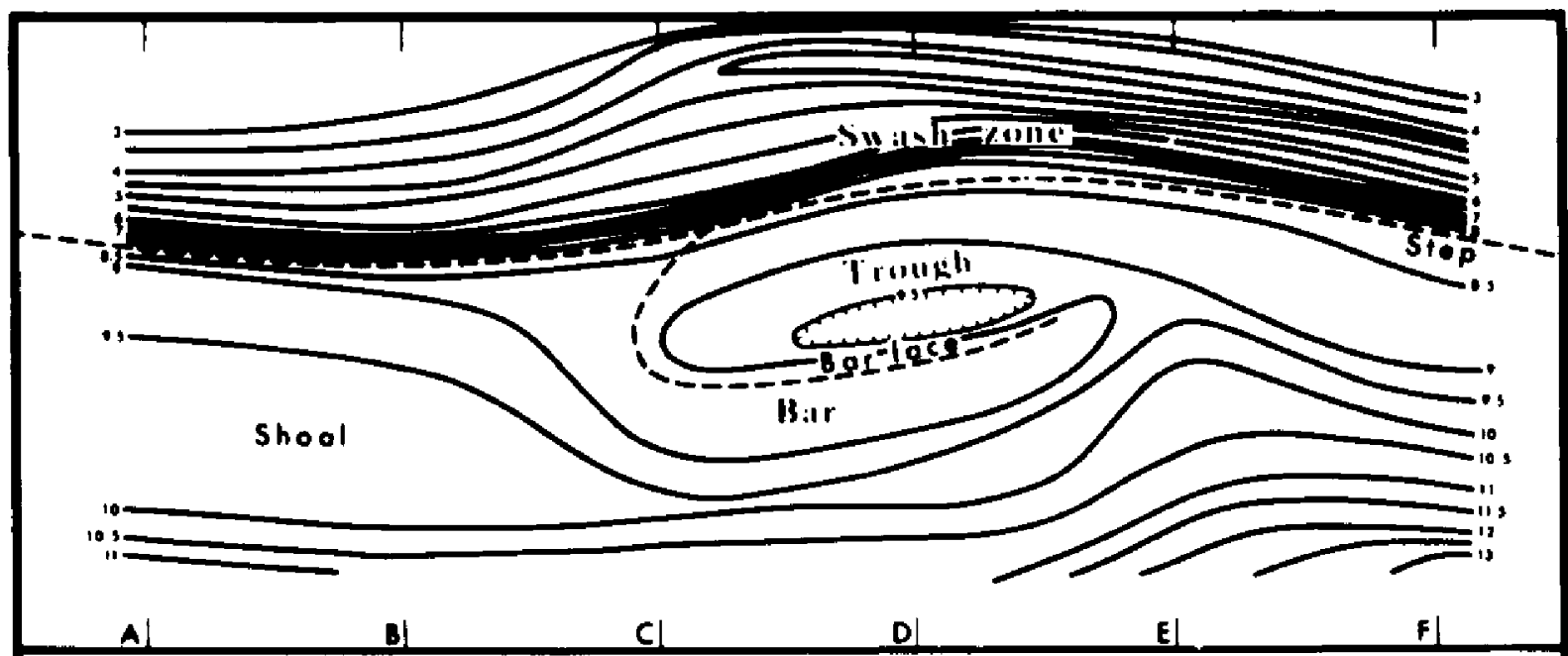

Still water level at trocer inpul 7.82 teet

(o) Site 1

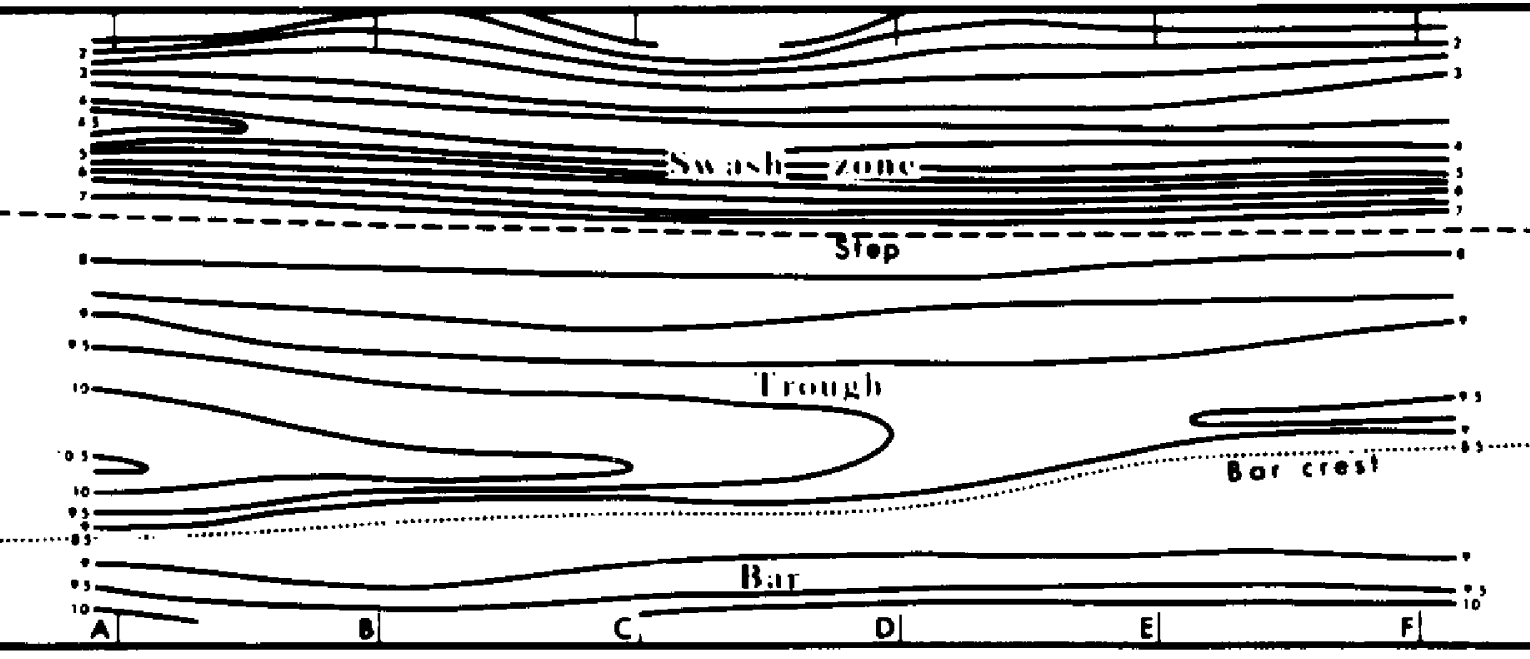

Still woter level at tracer input

Experiment 2683 teet

Experiment 36.52 feel

(b) Site 2

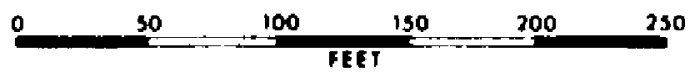

10 Contours in feet below local bench mark

C.I. 0.5 feet

Control: Experiment 195 surveyed points

Experiments 2 and 3108 surveyed points

Figure 3. Contour maps of beach topography. 


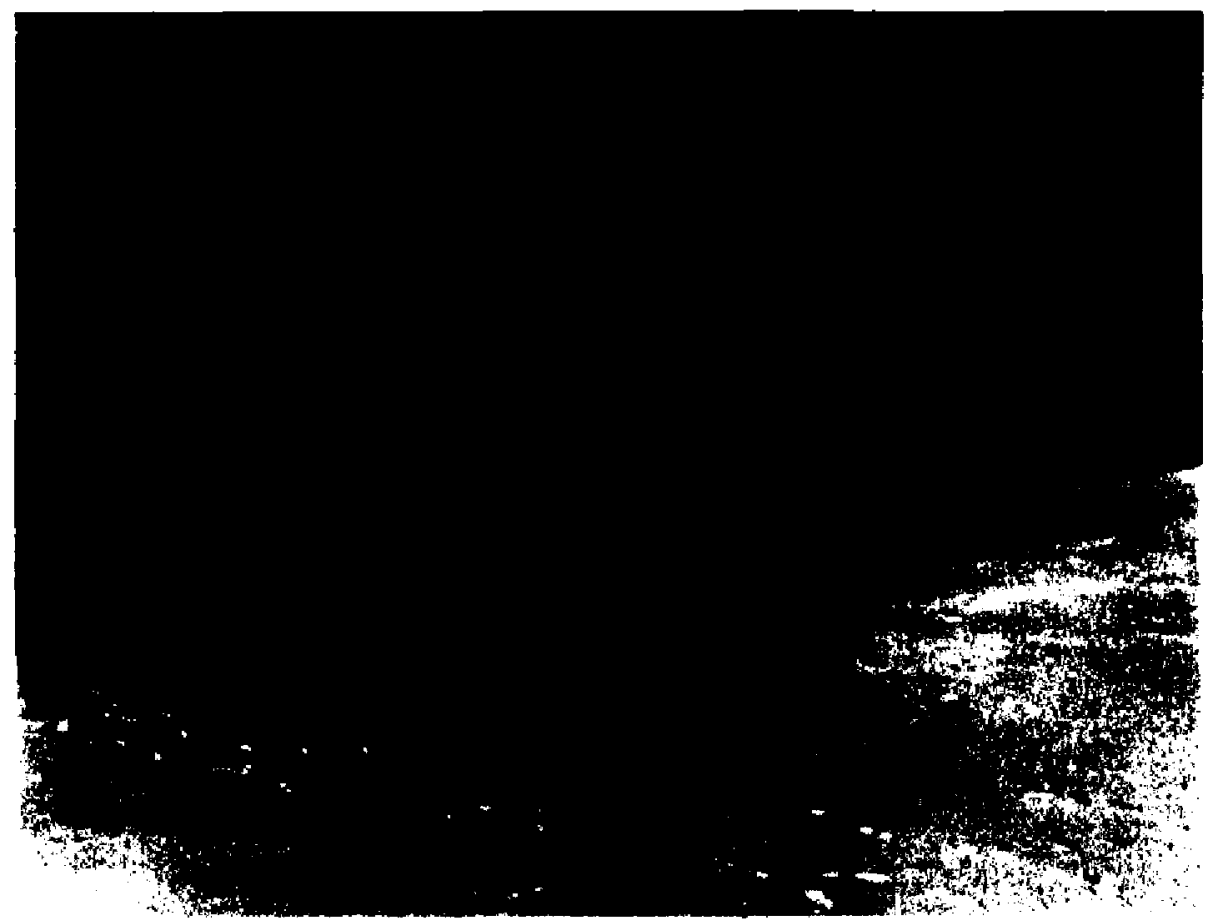

Figure 4. Site of experiment 1

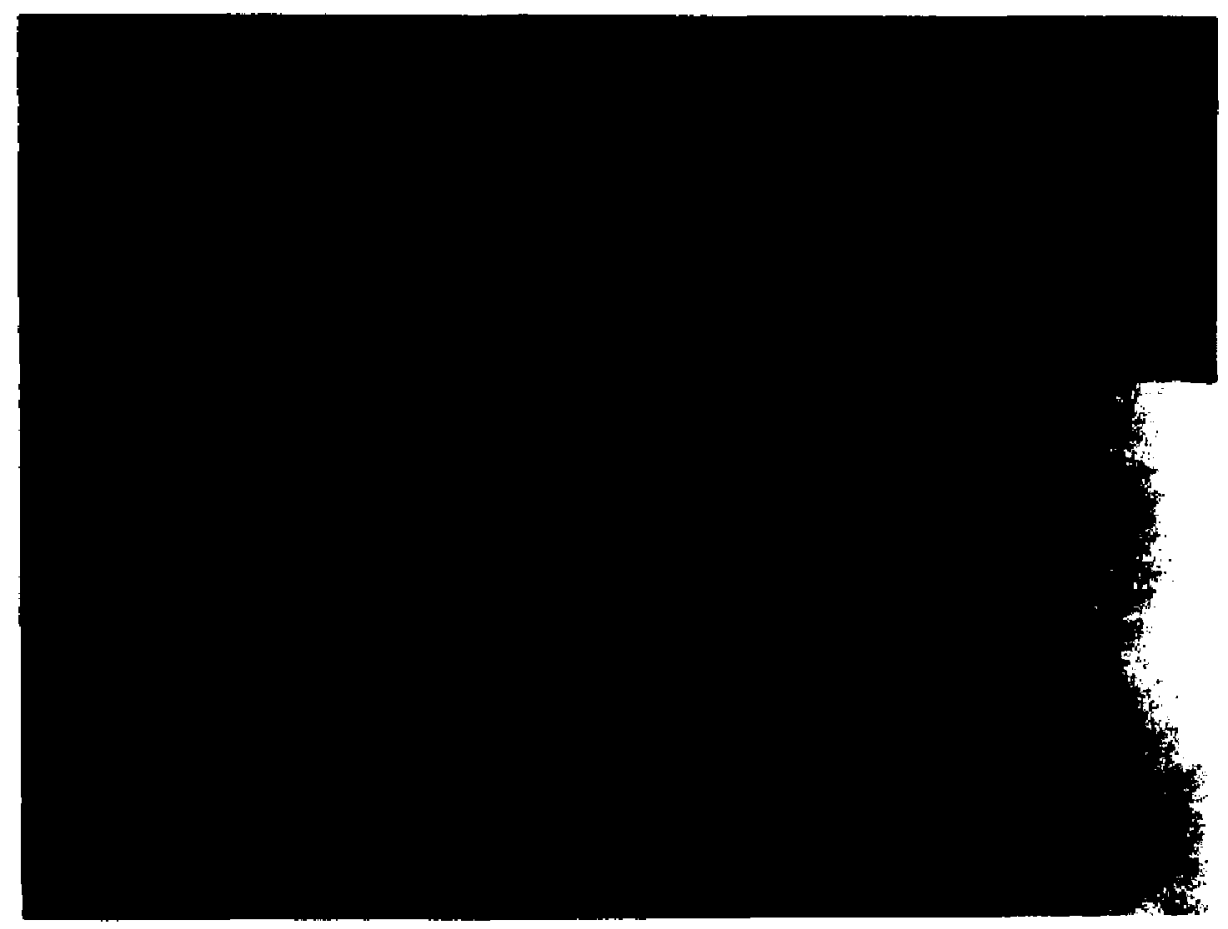

Figure 5. Site of experiments 2 and 3 
the beach system be similar to sediment within the system. Steps were therefore taken to maximize agreement between the physical properties of tracer and of beach sand present at tracer release points. Sand to be tagged was collected several hours before the beginning of experiments at the exact locations where tracer would later be released. Agreement In size-distribution statistlcs of tagged and untagged sand samples was verified statistically using the version of student's " $t$ " test appropriate to paired samples (Steel and Torrie, 1960, p. 78). Untagged sand samples were taken from release points at the time that tracer was introduzed into the beach system. Mean differences between tagged and untagged sand were for all size measures statistically not significant (Table I). Shape changes in small tracer samples were qualitatively assessed as negligible by viewing grains beneath a binocular microscope.

At low tide, 5-k1logram batches of color-differentiated tracer were released in three beach zones: the swash slope, bar, and intervening trough (Figure 6). Prior to release, tracer was mixed with detergent and sea water to suppress a floating tendency of the tagged material.

Tracer dispersion was documented over space and time. Areal dispersion from the three release points was established by counting the number of tracer grains of different colors present in thirty sediment cores. Samples collected from experiments 1 and 2 were counted with respect to three tracer colors. Those from experiment 3 contained six colors on account of that experiment being run at the same location as experiment 2. Cores measured 2 inches in diameter by 4 inches deep and were collected over sampling grids delimited on Figure 6. Dispersion through time was derived by repeating the 
Table I

SUMMARY OF PAIRED STUDENT' $s$ " $t$ " TESTS BETWEEN SIZE STATISTICS OF TAGGED AND UNTAGGED SAND

\begin{tabular}{lcccc}
$\begin{array}{c}\text { Size } \\
\text { Statistic }\end{array}$ & $\mathrm{n}$ & $\overline{\mathrm{d}}$ & $\mathrm{s}_{\overline{\mathrm{d}}}$ & $\begin{array}{c}\text { Computed } \\
\text { "t" }\end{array}$ \\
\hline Mean & 9 & 0.0471 & 0.0359 & $1.3120 \mathrm{NS}$ \\
Variance & 9 & -0.0320 & 0.0272 & $-1.1765 \mathrm{NS}$ \\
Skewness & 9 & -0.0176 & 0.0437 & $-0.4027 \mathrm{NS}$ \\
Kurtosis & 9 & 0.1101 & 0.2525 & $0.4360 \mathrm{NS}$ \\
\hline
\end{tabular}

NS Not significant

$t=\frac{\bar{d}}{s_{\bar{d}}} \quad d . f .=(n-1) \quad d$ values: tagged minus untagged size

Table II

SUMMARY OF ANALYSIS OF VARIANCE

ON SAMPLE REPLICATIONS AROUND SAMPLING STATIONS

\begin{tabular}{|c|c|c|c|c|}
\hline \multirow[b]{2}{*}{$\begin{array}{l}\text { Source of } \\
\text { Varlation }\end{array}$} & \multirow[b]{2}{*}{ d.f. } & \multicolumn{3}{|c|}{ Computed F Values } \\
\hline & & $\begin{array}{l}\text { Swash } \\
\text { tracer }\end{array}$ & $\begin{array}{l}\text { Trough } \\
\text { tracer }\end{array}$ & $\begin{array}{l}\text { Bar } \\
\text { tracer }\end{array}$ \\
\hline Total & 119 & & & \\
\hline Sampling station & 29 & $18.9529 \star \star$ & $8.4375 * \star$ & $7.5573 \star *$ \\
\hline Sample replication & 3 & 0.5018 NS & 1.3125 NS & $0.4016 \mathrm{NS}$ \\
\hline Error & 87 & & & \\
\hline
\end{tabular}

** Significant at the .01 level

NS Not significant 


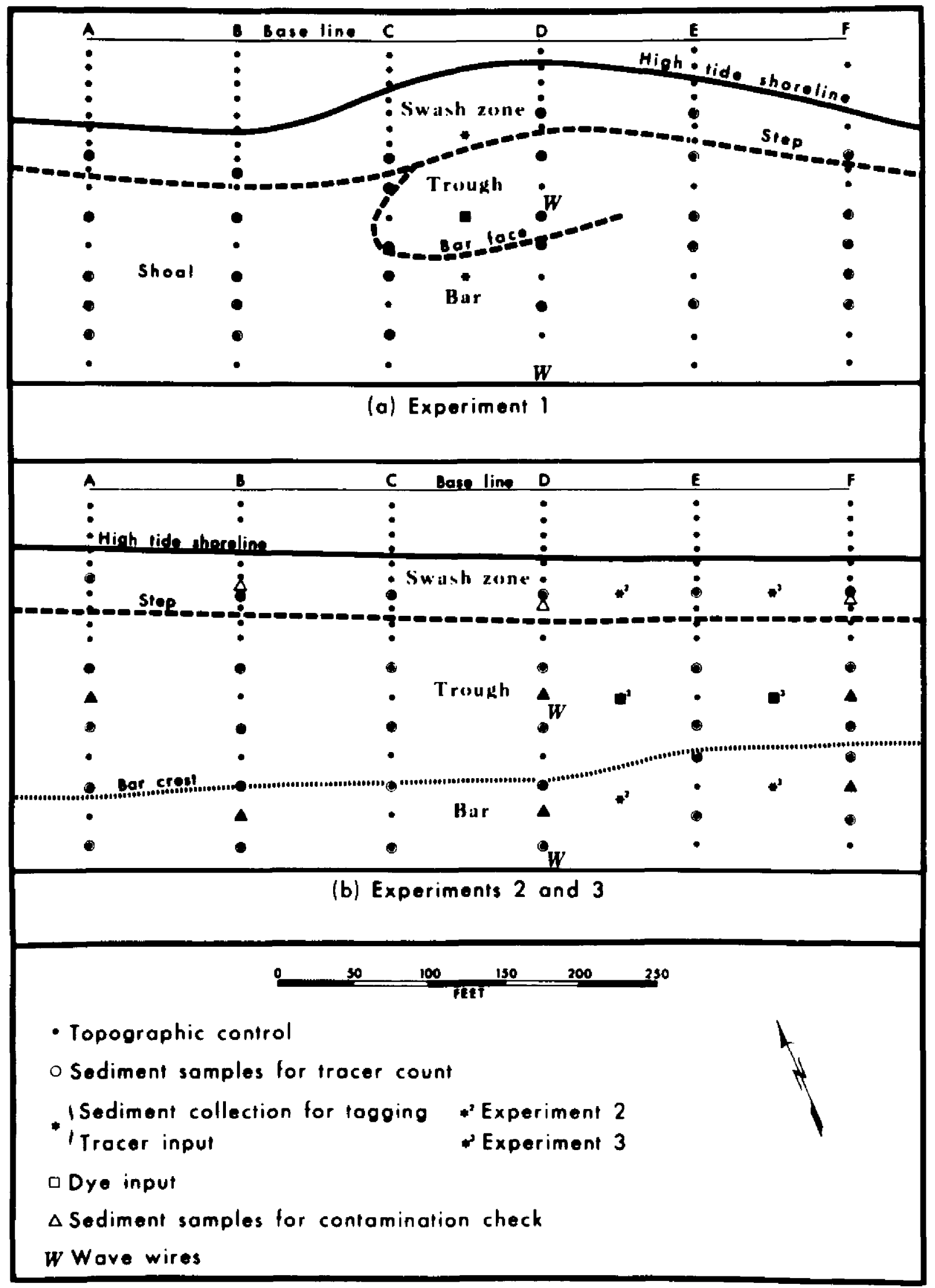

Figure 6. Field plans. 
sampling procedure at 1-,2-,3-, and 24-hour lags from the time of tracer release, except that no 24-hour lag data were collected for experiment 3. Tracer data of experiment 2 for 48-, 49-, and 50-hour lags are time equivalent to 1-, 2-, and 3-hour lag data of experiment 3.

In view of the fact that accuracy of further analysis is largely dependent on the reproduciblilty of the aforementloned procedures, assessments of sampling and operator error assoclated with the procedures are included at this point. The validity of establishing tracer dispersion patterns from a grid of point samples was checked by replicating around sampling stations sediment cores from which tracer concentrations were derived. Tracer frequencles of each core were analyzed according to a randomized-block analysis-ofvariance design (Steel and Torrie, 1960, pp. 132-137). Separate analyses were run for tracer released in each of the three beach zones. In all cases variation between samples taken at the same station was not significant (Table II). It was concluded that for conditions under which the analyzed data set was collected, one point sample satisfactor 11 y characterizes tracer concentration in the general vicinity of a sampling station. It 1s not unreasonable to extend this conclusion to cover samples collected during tracer experiments.

As a check on counting accuracy, a repeat count of tracer grains was made on thirty randomly selected sediment samples. A chi-square test (Steel and Torrie, 1960, pp. 346-351) was run on data of the two counts, grouped also by tracer color (Table III). The non-significant outcome indicates satisfactory reproducibility 
Table III

SUMMARY OF CHI-SQUARE TEST ON GRAIN COUNT REPLICATION

\begin{tabular}{|l|rrr|rrr|rrr|}
\hline \multirow{2}{*}{$\begin{array}{l}\text { Tracer } \\
\text { Color }\end{array}$} & \multicolumn{3}{|c|}{ Ist count } & \multicolumn{3}{c|}{ 2nd count } & \multicolumn{3}{c|}{ Total } \\
\cline { 2 - 9 } Blue & 84 & 88.50 & 0.2288 & 99 & 94.50 & 0.2142 & 183 & 183 & 0.4430 \\
Aqua & 8 & 10.64 & 0.6550 & 14 & 11.36 & 0.6135 & 22 & 22 & 1.2685 \\
Orange & 188 & 182.33 & 0.1763 & 189 & 194.67 & 0.1651 & 377 & 377 & 0.3414 \\
Purple & 599 & 587.12 & 0.2403 & 615 & 626.88 & 0.2251 & 1214 & 1214 & 0.4654 \\
Pink & 10 & 12.09 & 0.3612 & 15 & 12.91 & 0.3383 & 25 & 25 & 0.6995 \\
Green & 130 & 138.32 & 0.5004 & 156 & 147.68 & 0.4687 & 286 & 286 & 0.9691 \\
\hline Total & 1019 & 1019.00 & 2.1620 & 1088 & 1088.00 & 2.0249 & 2107 & 2107 & 4.1869 \\
\hline
\end{tabular}

$$
\begin{aligned}
0 & =\text { observed frequency } \\
\mathrm{E} & =\text { expected frequency } \\
& =\frac{\sum \text { row } \mathrm{x} \sum \text { column }}{\text { Grand total }} \\
\mathrm{x}^{2} & =\frac{(0-\mathrm{E})^{2}}{\mathrm{E}}
\end{aligned}
$$

$\sum X^{2}=4.1869 \quad(5$ d.f. $)$ NS

Tabled $x_{.05}^{2}=11.1$ (5 d.f.)

NS Not significant 
in tracer counting.

MAPPING TRACER DISTRIBUTIONS

Areal variation in tracer concentration is described by isolines drawn around mapped tracer frequencles (F1gures 10 through 12). A Iinear 1soline Interval proved impractical because data sets commonly contained several relatively high tracer frequencles close to the tracer source, whereas the majority of values were relatively very 1ow. The choice of a logarithmic interval enabled satisfactory representation of the data surfaces. Fitting of lsolines was based on the assumption of exponential change in concentration between data points. Crickmore and Lean (1962) have established by flume studies an approximate negative exponential relationship between tracer frequency and distance from source. Because of the impracticabllity of counting tracer grains in samples taken close to the source point, an arbitrary value of $10^{5}$ was assigned to release locations when negative gradients existed away from the source. The arbitrary value was large when compared to counted tracer values. An initial positive gradient was taken to indicate movement of the tracer centrold away from the source point.

Following a logarithmic transformation of tracer frequencles, isolines were linearly Interpolated between data points, with the following exceptions:

1) If all data values updrift from the sites of tracer release were zero, it was assumed that no tracer moved In that direction.

2) If tracer released in the swash zone was absent in samples collected seaward of the beach step, it was assumed 
that none of this tracer had crossed the beach step. Similarly, if tracer released in the trough and bar zones was absent in samples collected landward of the beach step, it was assumed that such tracer did not reach the swash zone. In these cases dummy values of zero were placed at the position of the beach step.

3) Because only one swash-zone sample was collected from each sampling traverse, the arrangement of isolines on the upper swash slope was determined by exponential extrapolation of tracer concentration to the limlt of wave swash. The extrapolation procedure most probably overestimates tracer quantities on the upper swash slope, but the pattern of isolines is considered to approximate what would have been obtained from tighter sampling control. Strahler (1966) has found that during flood tide, on a beach similar to that of Hurricane Island, deposition occurs at the swash limit, while erosion proceeds over the middle swash zone. The implication is that swash-zone sediment is moved upslope during rising tide. Tracer studies by Wright (1962) and by Boon (1968) document such movement. Wright reports that tracer also moves upslope during falling tide. Strong concentrations of tracer in swash marks were regularly observed during field work.

MEASUREMENT OF WAVES AND CURRENTS

During tracer programs data were obtained on wave helght, period, and angle of approach, and on trough current pattern and velocity. Two 10-minute continuous wave records were monitored 
from each of two measuring stations (Figure 6) following tracer re1ease. Components of the wave recording system are shown schematically in Figure 7. Wave helghts and perlods were derived from the records according to a procedure (Figure 7) published by Draper (1966). Angle of wave approach was measured with a Brunton compass. A summary of wave statistics and recording times is compiled in Table IV.

Currents were documented by a dye solution of potassium permanganate and sea water which was released in the trough (Figure 6) 1.5 hours after tracer input. D1spersion patterns and current velocities presented in Figure 8 are considered to provide a gross picture of current conditions for the first 2 hours of each experiment.

Tides were dally and tidal ranges for experiments 1 through 3 were $1.7,1.6$, and 0.8 feet respectively. 


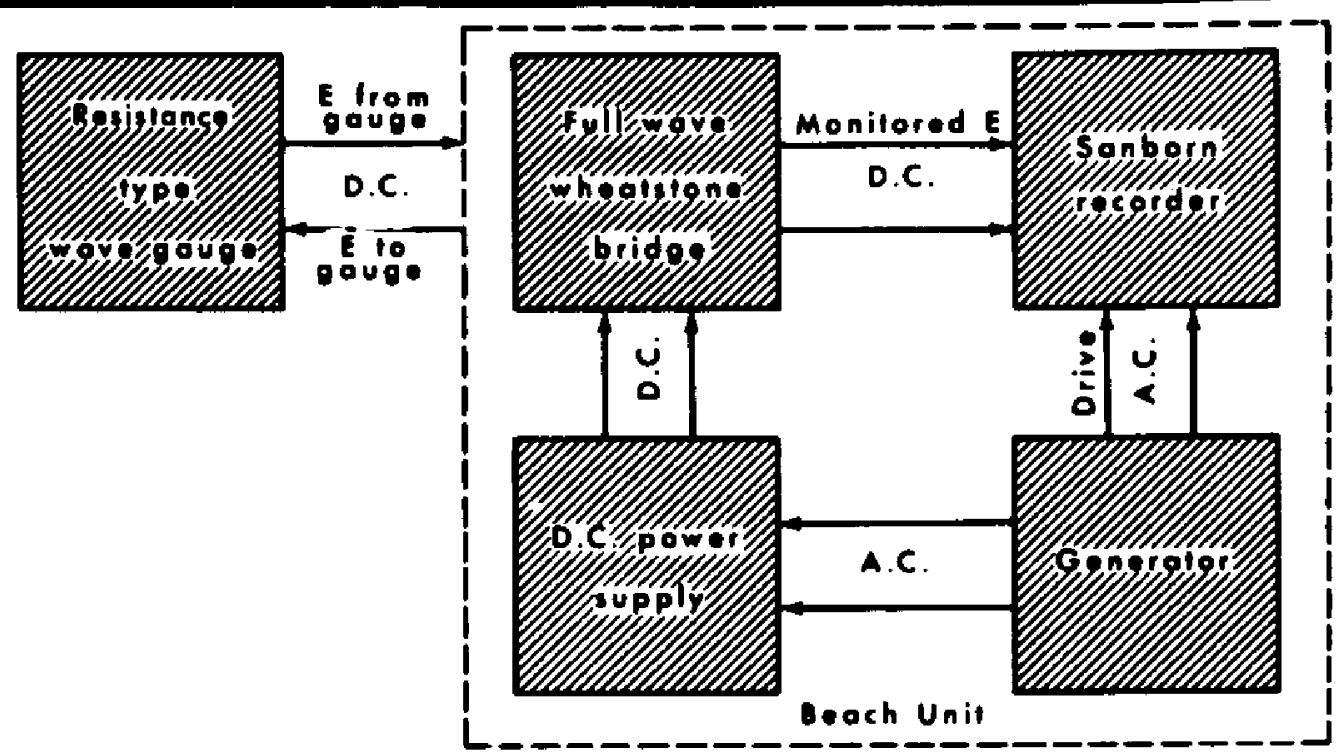

(a) Components of recording system

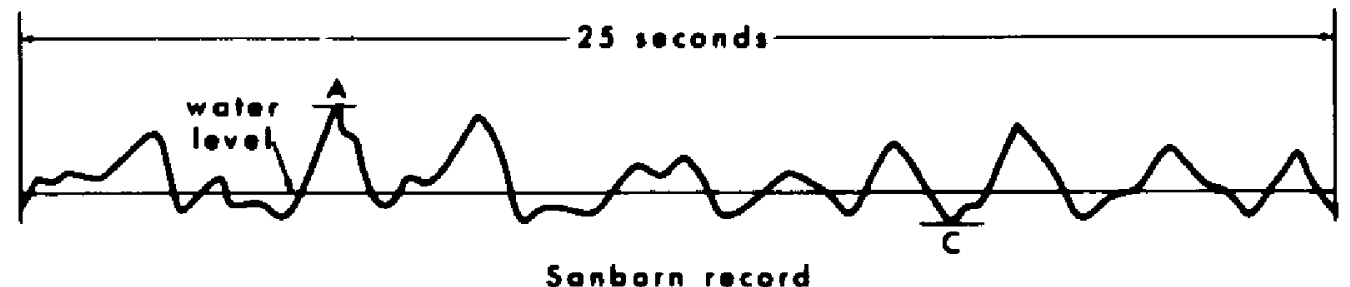

Total crosings $=20$

$N_{2}=\frac{\text { total }}{2}=10$

$T_{z}=\frac{\text { length }}{N_{2}}=2.5 \mathrm{secs}$.

$=$ wove period

$A=$ max. crest deviation from water level

$C=$ mox. trough deviation from woter level

$H_{1}=A+C(m m)$

$H_{1}=H_{1}$ converted to inches of water level motion

$H_{s}=H_{1} \times$ labled volue (Draper, 1966)

= meosure of wore height

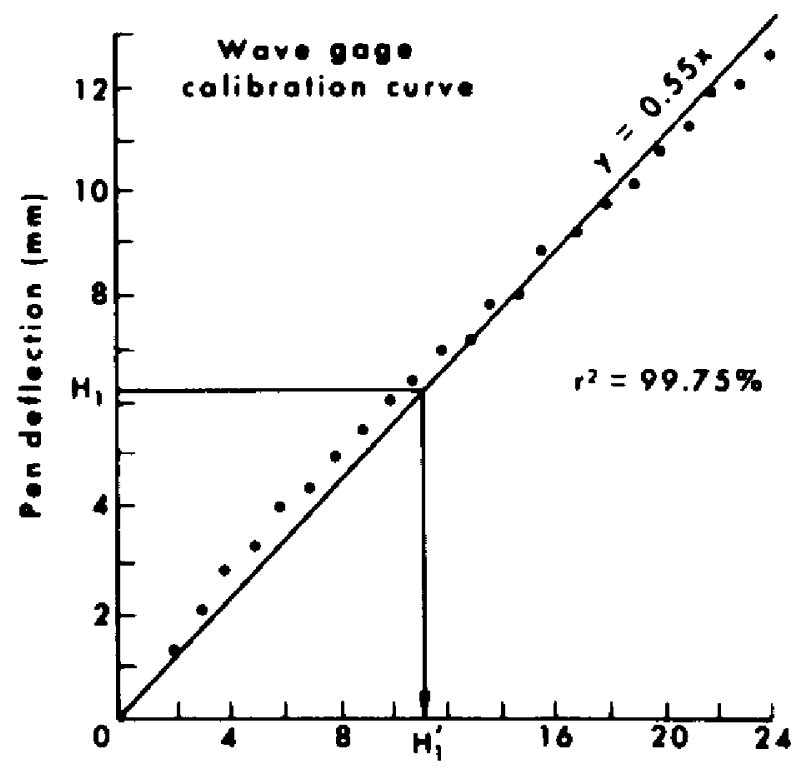

(b) Computation of wave height and period

water movement on gage (inches)

Figure 7. Collection and reduction of wave records. 
Table IV

SUMMARY WAVE STATISTICS

\begin{tabular}{|c|c|c|c|c|c|c|c|}
\hline \multirow{2}{*}{\multicolumn{2}{|c|}{$\begin{array}{l}\text { Experiment number } \\
\begin{array}{c}\text { Time of tracer } \\
\text { release - hours }\end{array}\end{array}$}} & \multicolumn{2}{|c|}{1} & \multicolumn{2}{|c|}{2} & \multicolumn{2}{|c|}{3} \\
\hline & & \multicolumn{2}{|c|}{1200} & \multicolumn{2}{|c|}{1500} & \multicolumn{2}{|c|}{1400} \\
\hline \multicolumn{2}{|c|}{$\begin{array}{c}\text { Time of record } \\
\text { hours }\end{array}$} & 1215 & 1530 & 1515 & 1830 & 1415 & 1730 \\
\hline \multirow{4}{*}{$\begin{array}{l}\text { Trough } \\
\text { record }\end{array}$} & $\underset{f e e t}{d}$ & 1.81 & 2.34 & 2.19 & 2.49 & 2.47 & 2.55 \\
\hline & $\begin{array}{l}H_{O} \\
\text { feet }\end{array}$ & 1.79 & 1.75 & 1.09 & 0.48 & 1.61 & 1.48 \\
\hline & $\begin{array}{c}T \\
\text { secs. }\end{array}$ & 3.43 & 3.77 & 2.34 & 2.88 & 2.48 & 3.00 \\
\hline & $\mathrm{H}_{\mathrm{o}} / \mathrm{L}_{\mathrm{o}}$ & .030 & .024 & .039 & .011 & .051 & .032 \\
\hline \multirow{6}{*}{$\begin{array}{l}\text { Bar } \\
\text { record }\end{array}$} & $\stackrel{d}{\text { feet }}$ & 3.07 & 3.62 & 3.38 & 3.71 & 3.65 & 3.71 \\
\hline & $\begin{array}{c}\mathrm{H}_{\mathrm{O}} \\
\text { feet }\end{array}$ & 2.07 & 2.37 & 0.65 & 0.40 & 0.75 & 0.59 \\
\hline & $\begin{array}{c}T \\
\text { secs. }\end{array}$ & 3.26 & 3.68 & 2.33 & 2.86 & 2.54 & 3.16 \\
\hline & $H_{o} / L_{o}$ & .038 & .034 & .024 & .010 & .023 & .012 \\
\hline & $\begin{array}{c}\ominus \\
\text { degrees }\end{array}$ & 14 & 14 & 4 & 4 & 19 & 14 \\
\hline & $\begin{array}{l}\text { Breaker } \\
\text { position }\end{array}$ & \multicolumn{2}{|c|}{$\begin{array}{c}\text { Bar } \\
\text { and } \mathrm{B} \text { tep }\end{array}$} & \multicolumn{2}{|c|}{$\begin{array}{l}\text { Step } \\
\text { only }\end{array}$} & \multicolumn{2}{|c|}{$\begin{array}{l}\text { Bar } \\
\text { (h1gher } \\
\text { waves) and } \\
\text { step }\end{array}$} \\
\hline
\end{tabular}
d Water depth at wave gauge position
$\mathrm{H}_{\mathrm{o}} / \mathrm{L}_{\mathrm{o}}$ Deep-water wave steepness
$\mathrm{H}_{\mathrm{O}}$ Deep-water wave height
$\theta$ Wave incidence (angle between wave crest and shoreline)

T Wave period 


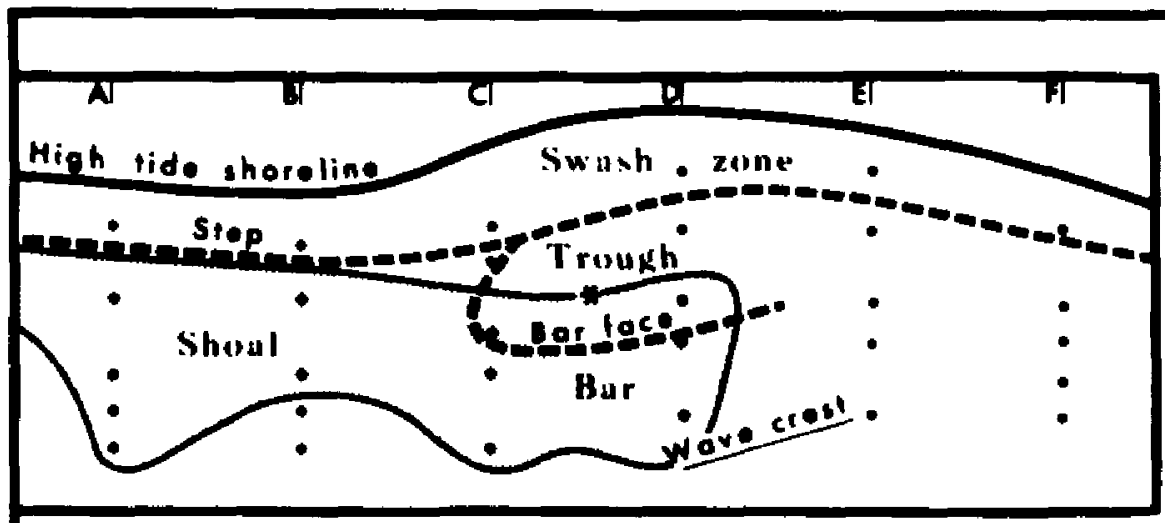

(a) Experiment I

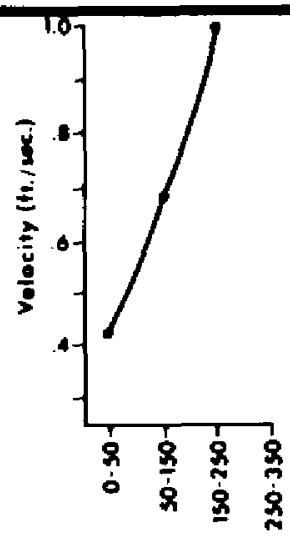

foet from relesen ot.
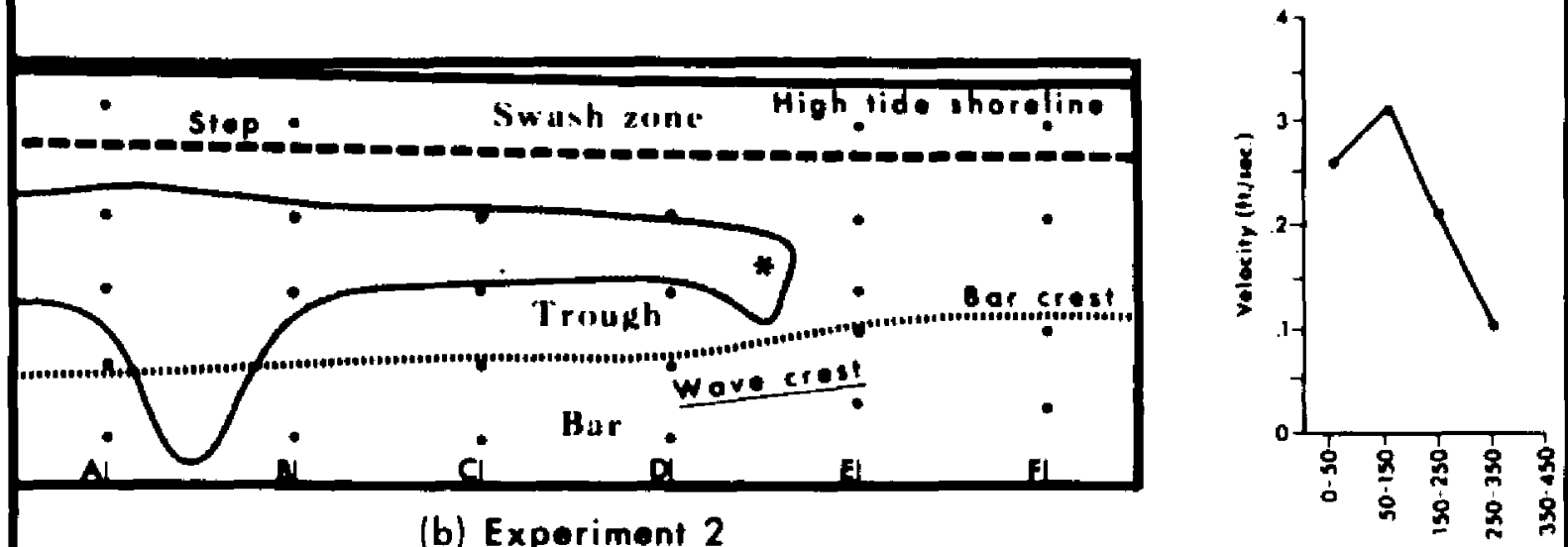

(b) Experiment 2

Feer trom rateow pi.
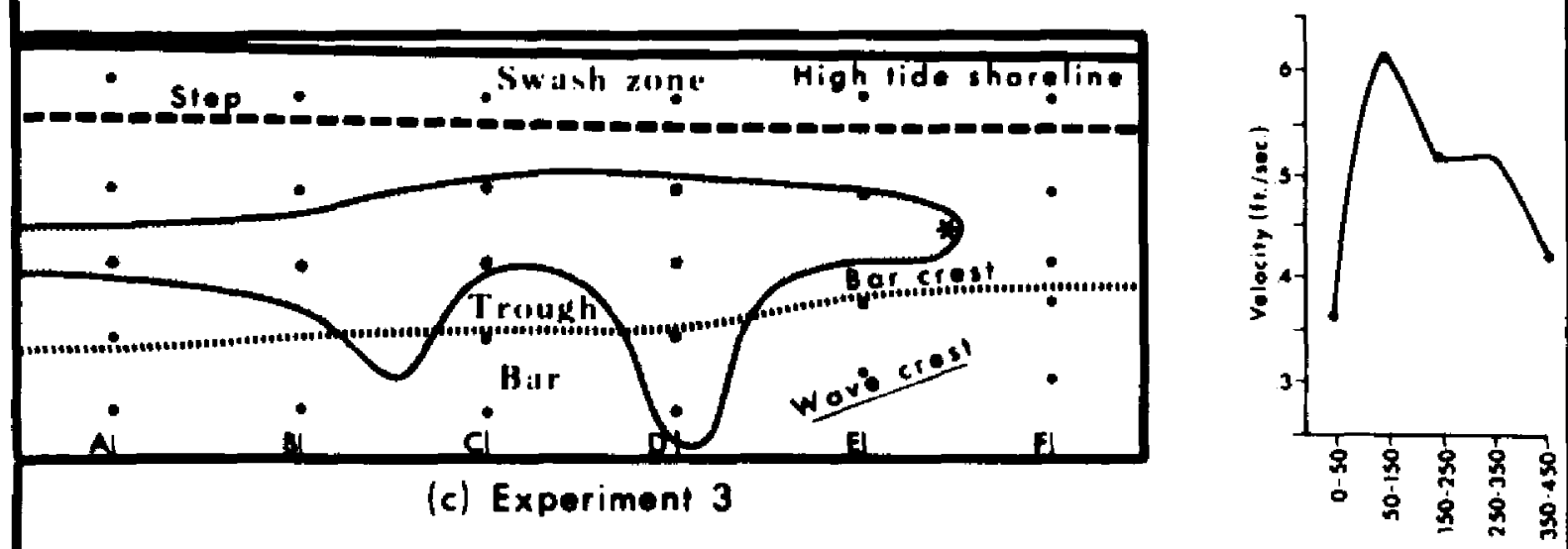

(c) Experiment 3

Feel from releoste pr.

\begin{tabular}{lllll}
0 & $50 \quad 100 \quad 150$ & 200 & 250 \\
\hline & &
\end{tabular}

* Dye release

Dye patch after dye front cleared controlled area 
TRACER DISPERSION

MEDIAN PATHS OF TRACER MOTION

Crestlines of tracer concentration surfaces represent median paths of tracer motion. These are compiled on Figure 9. Brief descriptions of tracer movement from the three sources, as summarized on Figure 9 , are presented separately. Tracer Released in the Swash Zone

The beach step generally formed a boundary across which very little sediment was transported. Tracer released in the swash zone remained for the most part within that zone, being moved alongshore by the process of beach drifting. Exceptional to this generalization was the movement of swash tracer onto the subaqueous shoal during the later hours of the first tracer run. Minor amounts of tagged sediment also were transferred from the swash zone into the trough during experiment 2 .

Tracer Released in the Trough

No tracer placed in the trough was observed in sand samples taken from the swash slope, substantiating the aforementioned role of the beach step as a barrier to sediment transport under sea and beach conditions of the experiments. Although trough tracer moved predominantly alongshore in the direction of the 1ittoral current, some significant movement landward and seaward of trough axes took place, as also did transport updrift from points of tracer release. Throughout the early hours of the first experiment there was little movement of trough tracer. The charge was observed to spread as a broad patch, with downdrift asymmetry, around the release point. 


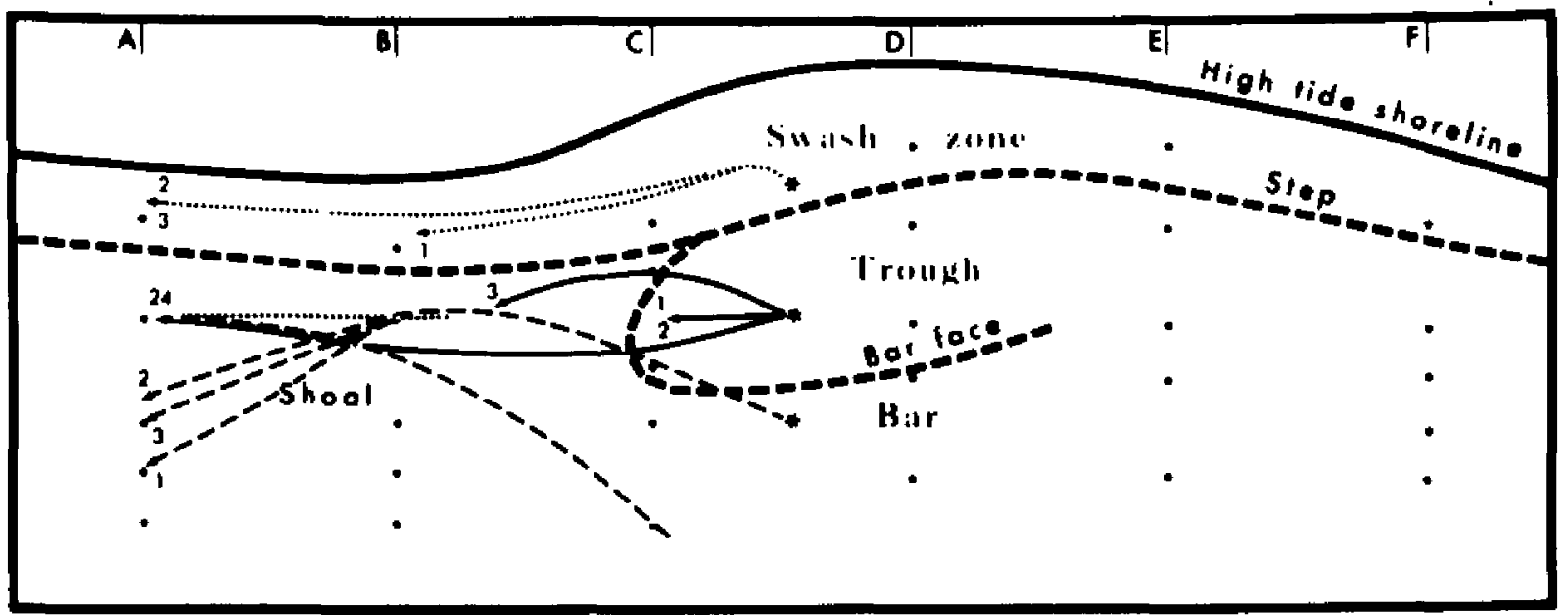

(a) Experiment 1

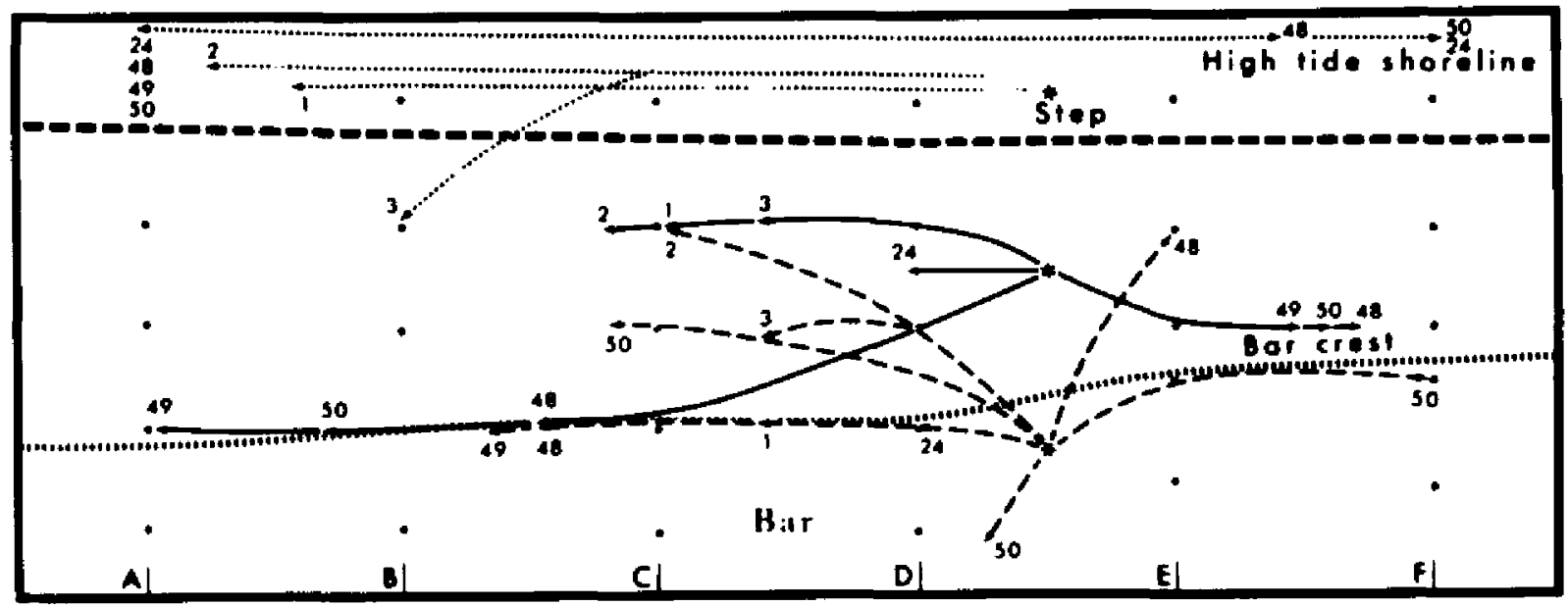

(b) Experiment 2

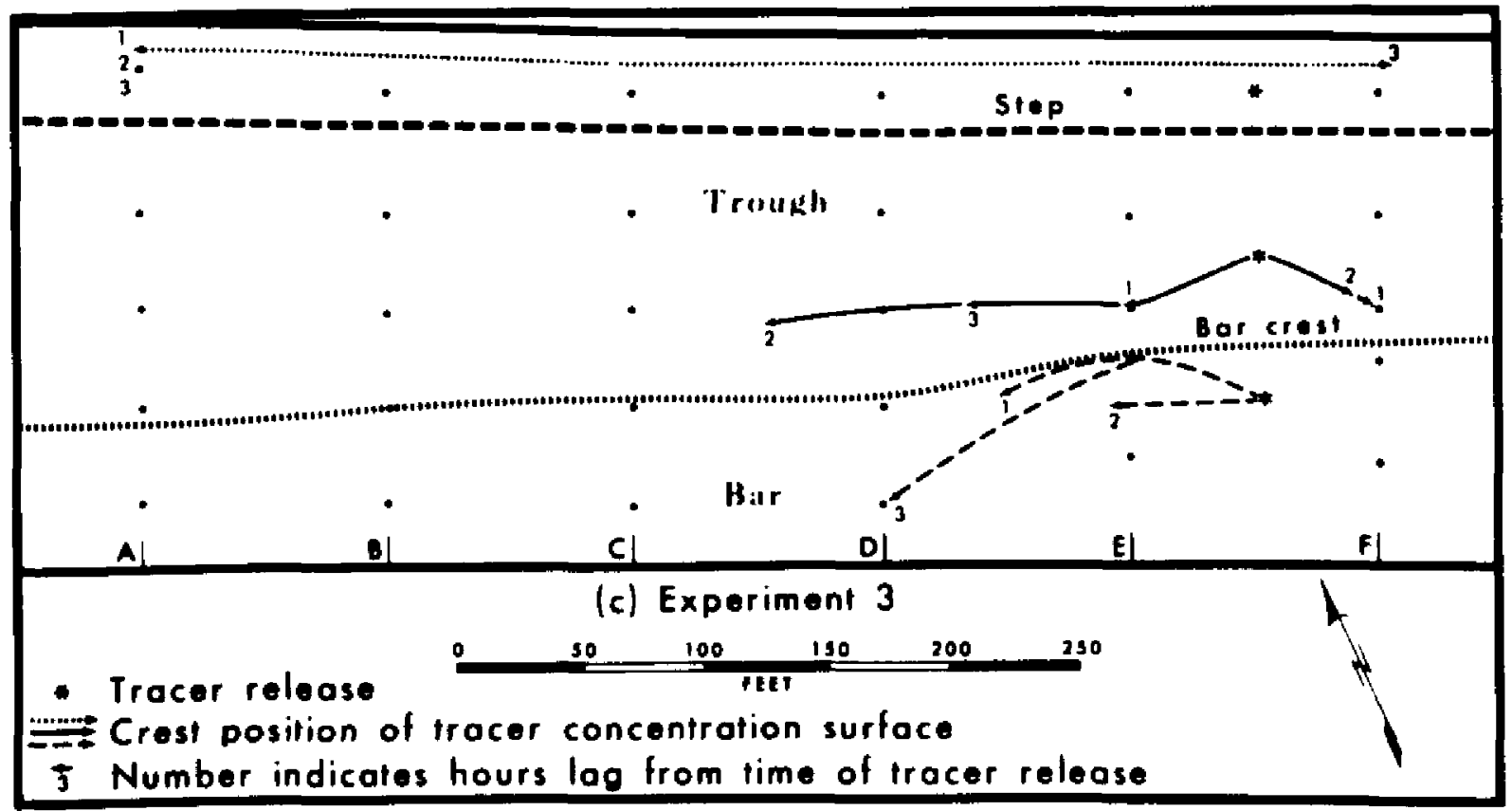

Figure 9. Crest positions of tracer concentration surfaces. 
Within three hours from tracer Input small amounts of tagged sand had moved downdrift, out of the trough, and onto the subaqueous shoal. Simllar transport continued throughout the tidal cycle, as poitrayed by the 24-hour lag data (Figure 9). During this time beach morphology at the site of experiment 1 was not in equilibrium with wave and current conditions. Topography was established during westerly storm conditions, whereas waves in the post-storm period approached shore from the southwesterly quadrant. Tracer placed in the trough moved in response to this prevalling sea state and exhibited no apparent relationship to subaqueous relief.

Beach morphology at the site of experiments 2 and 3 was less complex than at the locality of the initial experiment. A continuous trough ran between the beach step and the offshore bar, along which flowed an uninterrupted and well defined longshore current. of particular interest concerning tracer transport are deviations from a downcurrent path parallel to the beach trend. Deviations of three varieties were observed:

(1) Data of experiment 2 collected on the same day that tracer was placed in the beach system $(1-, 2-$, and 3 -hour lags) indicate a landward displacement of sediment during downcurrent movement.

(2) Data of experiment 2 collected 2 days after tracer input (48-, 49-, and 50-hour lags), together with simultaneously collected data of experiment 3 , indicate a seaward displacement of tagged grains during downcurrent transport. Tracer associated with the earlier experiment moved obliquely onto the bar, where 
it proceeded alongshore at the position of the bar crest.

(3) The same data sets 1ndicate tracer movement in the updrift direction with concurrent seaward displacement. In all cases the alongshore component was greater than the transverse, and downcurrent transport exceeded upcurrent transport.

Tracer Released on the Bar

Transport vectors of tracer placed on the bar were more varlable than were those of the trough or swash charges. Movement normal to the shore also was greater for bar tracer than for tracer charges placed in other beach zones, although the alongshore component remained greater than the transverse component.

Tracer movement throughout the first experiment was essentially downcurrent, with notable seaward movement near the downdrift boundary of the shoal during the initial 3 hours. The tracer source was depleted within 24 hours, at which time a considerable amount of tagged sediment remained on the shoal downdrift and seaward of the release point.

The 2-day collection program of experiment 2 yielded highly variable results. Phases of activity can nevertheless be enumerated: (1) Tracer moved downcurrent and into the trough during initial hours of the program; (2) data collected 2 days after tracer input indicate subsequent transport along the bar crest in both downcurrent and upcurrent directions, as well as localized offshore movement. Tracer of experiment 3 traveled offshore along a median path quite similar to that of concurrent movement of tracer of the second experiment. 
TRACER DISPERSION AND BEACH-PROCESS VARIABLES

Swash Zone

The process of beach drifting, whereby particles moved by wave uprush and backwash are transported alongshore through a series of parabolic arcs, 1s discussed at length by Johnson (1919, pp. 94-103). Field experiments such as those by Evans (1939) have clearly established its authenticity. Height and velocity of uprush are largely a function of wave helght, and to a lesser extent, of wave steepness. Beach gradient and sediment characteristics will modify the effects of wave geometry. Alongshore sediment transport has been shown by Zenkovich (1967, p. 319) to increase more than exponentially with increase in the angle of wave incidence, other factors being equal. Alongshore movement of swash tracer was considerably greater during experiment 3 than during experiment 2 for corresponding time periods (Figure 9). Th1s can be attributed to the combined effects of higher waves and a larger angle of wave incidence throughout the former experiment, since beach gradient and sediment characteristics were essentially constant. The first hour of experiment 1 appears contradictory to what would be expected from a consideration of wave conditions at that time. Waves measured in the trough were higher at the outset of the first experiment than for any phase of other experiments, but alongshore movement was the smallest recorded. A plausible explanation is one in terms of beach topography. Although tracer was placed in the swash zone landward of the trough, alongshore movement brought tracer to a position landward from a shallow subaqueous shoal (FIgure 3). Wave parameters recorded in the trough did not characterize waves traveling across the shoal. Shallow water 
here gave rise to a spilling-type breaker and refraction considerably reduced the alongshore component of wave uprush which followed the final collapse of the wave form.

Trough and Bar Zones

Relationships between inshore sediment transport and beach process variables are discussed separately for transverse movement and alongshore movement.

Transverse movement. It is commonly found in tank tests that the direction of transverse transport is highly correlated with wave steepness. A general rule has developed that inside the break point steep waves move beach material seaward while flat waves induce shoreward sediment movement (Johnson, 1949; Scott, 1954; Rector, 1954; K1ng, 1959, p. 127). A commonly cited critical steepness value above which seaward transport occurs is 0.03 , although variables such as sediment size and beach slope should be expected to introduce variation between specific situations. Data of the present report tend to substantiate the general rule. Seaward movement of tracer placed in the trough took place during the time of steepest trough waves. This was during the third experiment, with which 48-, 49-, and 50-hour lag data of experiment 2 are time equivalent. Averaging the two trough wave records collected during experiment 3 yields a steepness value of 0.042 , which is considerably larger than trough wave-steepness values of other experiments.

Shoreward movement of beach sediment generally is explained by the greater shoreward than seaward velocities of oscillatory wave currents, and by the mass forward motion of water particles in the wave form (see, for example, Grant, 1943; Scott, 1954; Rector, 1954). 
Relationships between sediment size and wave parameters are Important in this respect, but are not well understood.

Explanations of seaward sediment transport relate to various models of nearshore water circulation. The most simple model is that sediment moves in response to a rather uniform bottom seaward flow of water (commonly termed "undertow") whlch sets up to balance shoreward mass transport of water in the wave form. On this subject Zenkovich (1967, pp. 62-64) summarizes work by Longinov which indicates that flow of this type occurs not as constant currents but as "periodic movements corresponding in phase with the main wave movements." M11ler and Zelgler (1964) report field observation of a seaward return flow at mid-depth. The nature of seaward displacement of trough tracer during experiments 2 and 3 suggests response to unconcentrated water flow close to the bottom. It is doubtful whether under wave conditions present during data collection turbulence would have been of a magnitude large enough to lift sediment to a mid-depth level.

Early opposition to the 1dea of "undertow" was expressed by Shepard, Emery, and LaFond (1941) and by Grant (1943). These papers alternatively emphasize the role of rip currents in transporting water seaward. Dye was released in the trough during the Florida programs with the purpose of locating rip currents if these were present. Although no pronounced seaward flow was 1ndicated, the seaward dye boundary located over the bar crest was characteristically lobate (Figure 8), Indicating localized seaward water currents. Agreement between the location of seaward dye extenstons and seaward-moving tracer indicates that quasi-permanent weak rip currents may have transported some tracer seaward. Especially 
is this auggested by data collected over the bar during experiment 3 .

It is Important to note that seaward movement of trough and bar tracer occurred only when waves broke on the bar.

Alongshore movement. Alongshore sediment transport within the Inshore beach area is the product of direct wave action and wave-generated longshore currents. Field observations and theoretical considerations indicate that bottom shear stresses and turbulence associated with breaking and shoaling waves are the dominant forces in sediment entrainment, whlle transport is due malnly to currents other than those of wave motion.

Current velocities recorded during the Florida programs are positively correlated with wave helght and angle of wave approach, measured as the angle between the shoreline trend and wave crest. The data do not permit the effects of wave height and angle of approach on current velocity to be independently assessed. Sonu et al. (1966) found angle of wave approach to be more important than wave height or wave period in "explalning" variation in longshore current velocity. However, Harrison and Krumbein (1964), In a simflar type of analysis, ranked wave period first, followed by wave height. Angle of wave approach was ranked fifth. With reports conflicting to this extent, it is not possible to develop even general qualitative links between alongshore sediment transport and beach process variables. More detafled and precise information is required.

Alongshore transport vectors on the bar were generally greater than those in the trough when waves broke on the bar. The observation can be partially explained in terms of entrainment advantages on the bar due to greater turbulence produced by breaking waves. Ingle (1966, 
p. 71) cites work by Russian scientists Albulatov and Zenkovich which relates maximum sediment transport along bar crests with maxtmum longshore currents in the same vicintty.

Tracer data of experiment 3 and concurrent data of experiment 2 Indicate alongshore transport in the direction opposite to the recorded main current direction. Such transport could be interpreted as a response to feeder currents associated with seaward rip flow. The possibility of concentrated seaward flow across the bar has previously been mentioned with respect to seaward transport of bar tracer. Relative positions of seaward flow and feeder currents suggested by tracer transport, however, are not consistent with the rip-current model (Shepard et a1., 1941). If rip systems were active during data collection, their alongshore location could not have been very permanent. 


\section{SUMMARY AND CONCLUSIONS}

The experiments indlcate that transfer of sediment between beach zones (onshore-offshore movement) takes place within a clrculation of sediment which possesses a major alongshore directional component. Th1s appears to be true even when the angle between wave crests and the shoreline is small.

Only when a subaqueous shoal replaced the trough immediately seaward of the beach step did appreclable amounts of tracer move seaward from the foreshore. Otherwise the beach step formed a boundary across which little sediment was transported in either direction. This points to the significance of rhythmic beach topography (Sonu and Russe11, 1966) as a mechanism for transfer of sediment between the foreshore and inshore beach zones. A characteristic of such topography is the periodic merging of the bar with the foreshore to produce a series of subaqueous shoals along the shoreline. Although topography of this nature was not present during the time of data collection, it is known to develop commonly along the Florida coastline and along many other coastlines the world over.

Tracer released on the trough bottom and bar moved predominantly alongshore in response to currents generated by waves obliquely approaching the shoreline. Concurrent transport perpendicular to the shoreline can be related to wave steepness and wave-breaking characterlstics on the bar. Seaward movement of tracer released in the trough and on the bar took place only when waves broke on the bar, and was most marked when wave steepness had a value near 0.04 . During these conditions tracer released in the trough moved onto and along the bar crest. At other times landward movement accompanied alongshore 
transport such that tracer released on the bar moved into the trough. Dye tracing of currents did not establish the presence of well developed r1p-current systems, although several cases of alongshore movement in opposite directions could be interpreted as a response to feeder currents assoclated with weak rip systems. The nature of trough-tracer dispersion, however, was more suggestive of incremental seaward movement during alongshore transport than of concentrated seaward movement at specific locations, as required by the rip-current model.

Sea state during execution of tracer programs was low. Sediment movement was relatively sluggish and little change in beach morphology took place. Generalizations of sediment movement should be considered with these circumstances in mind. During higher sea conditions and at times when beach morphology is more rapidly changing it is probable that sediment transport is different from that documented by the present set of experiments. 

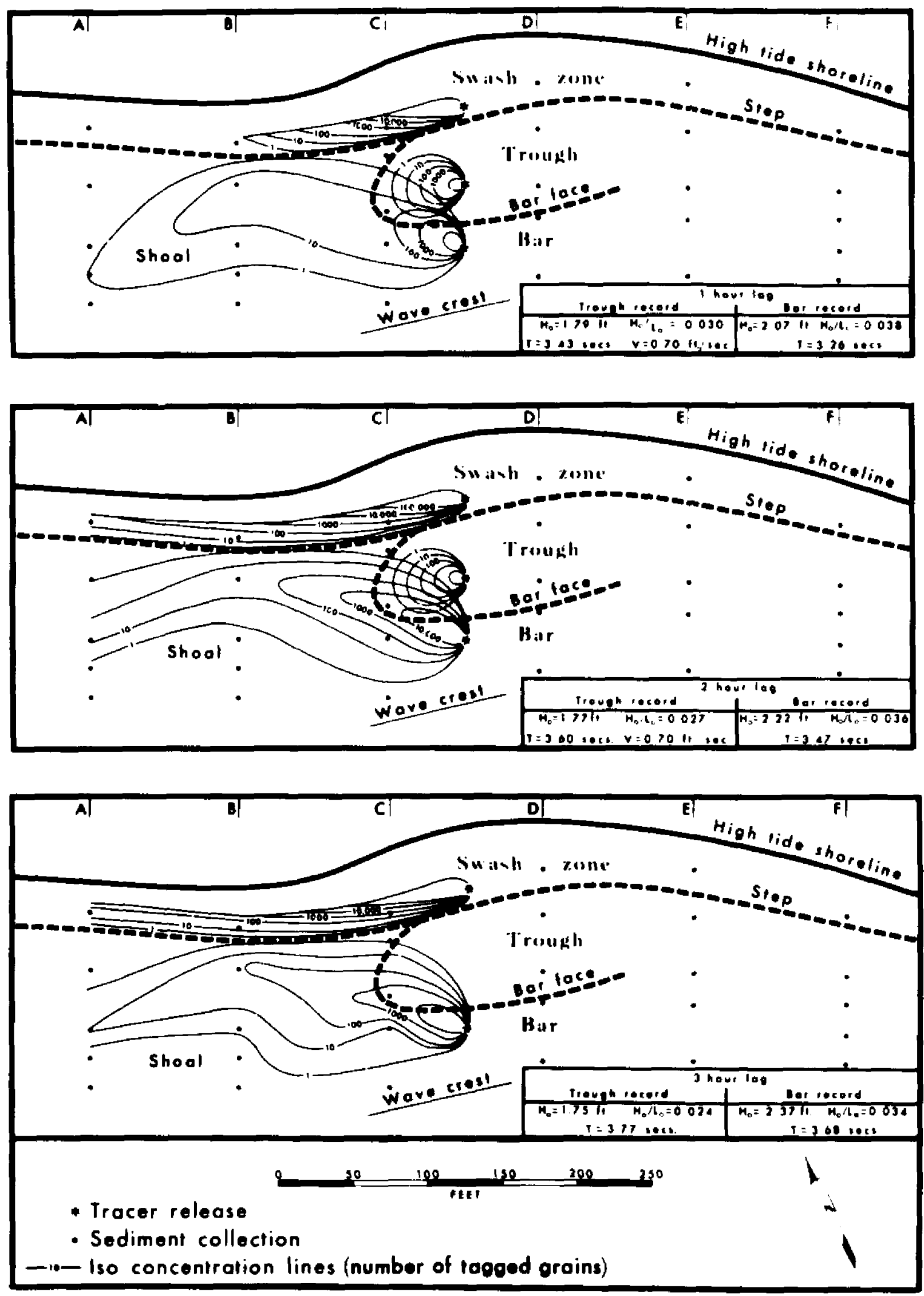

Figure 10 a. Tracer dispersion, experiment 1. 

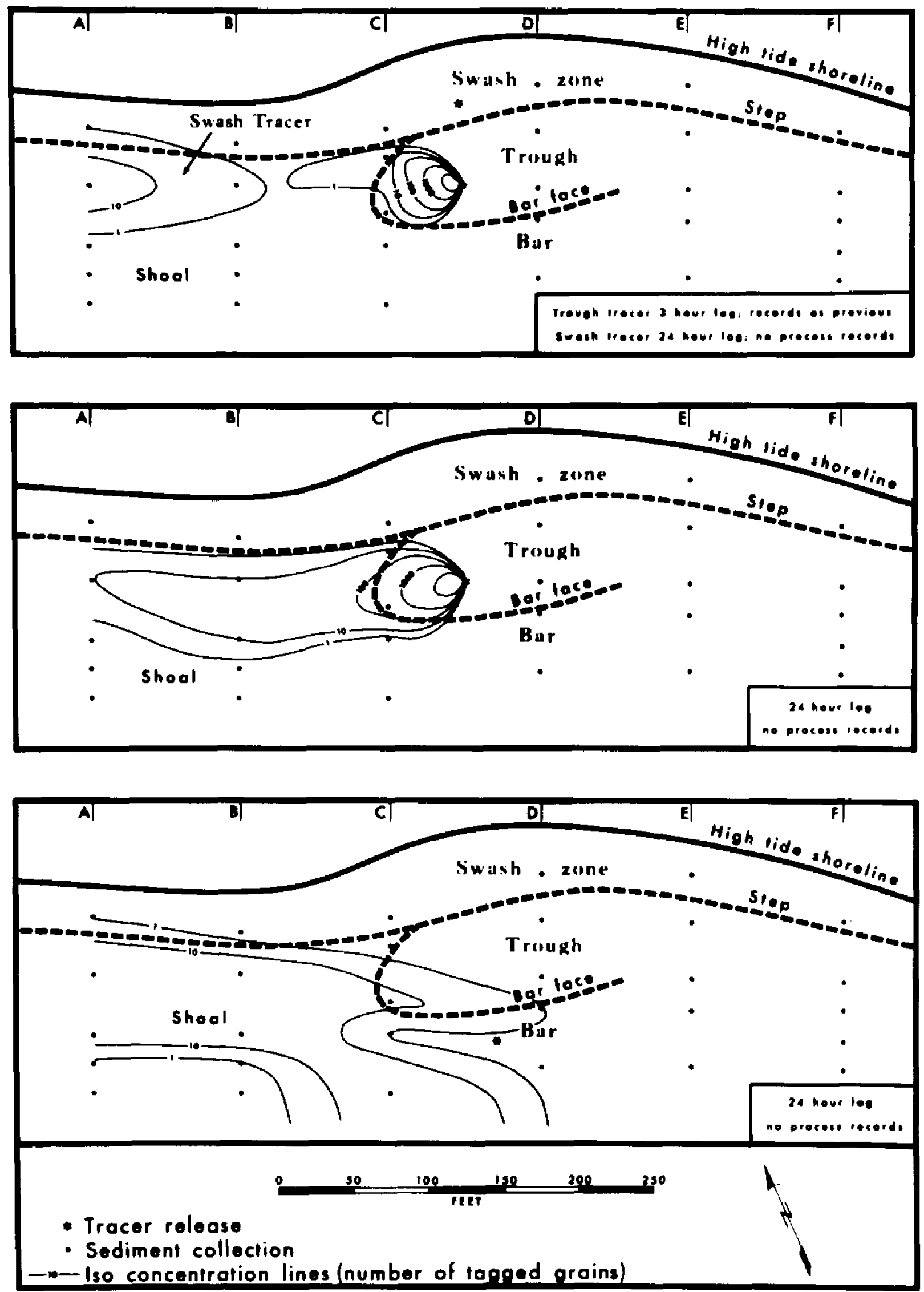

Figure 10 b. Tracer dispersion, experiment 1. 

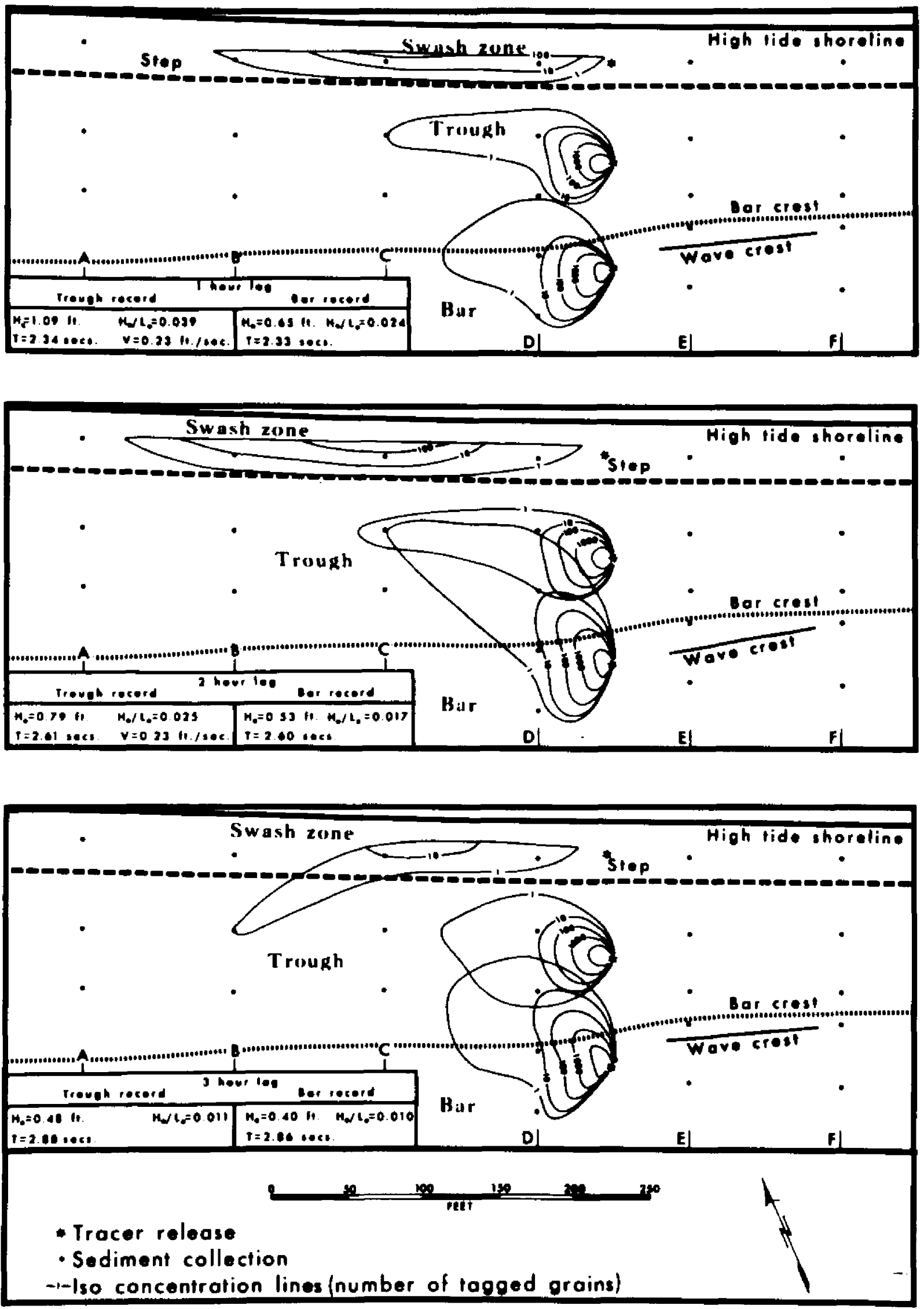

FIgure 11 a. Tracer dispersion, experiment 2. 

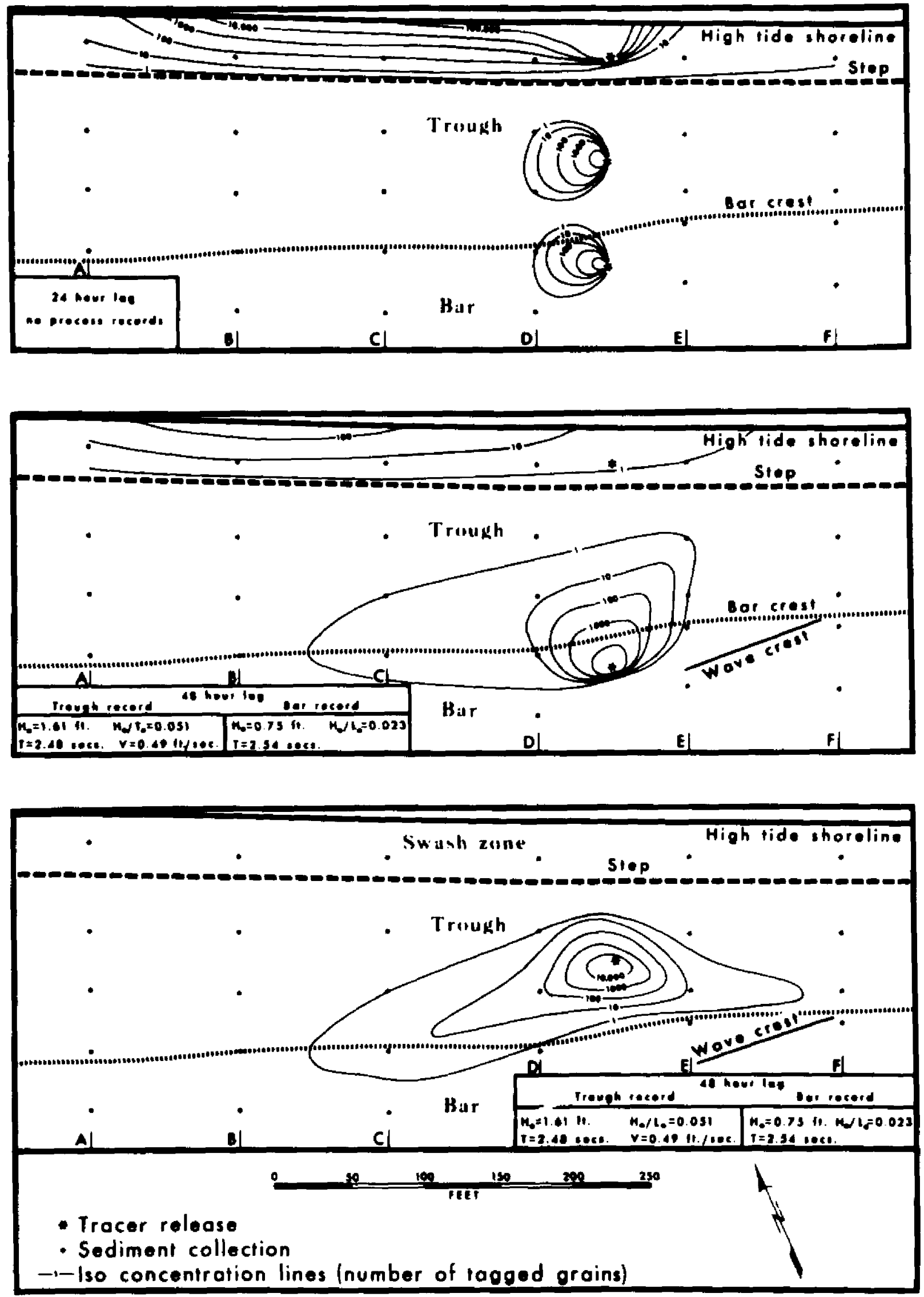

Figure 11 b. Tracer dispersion, experiment 2 . 

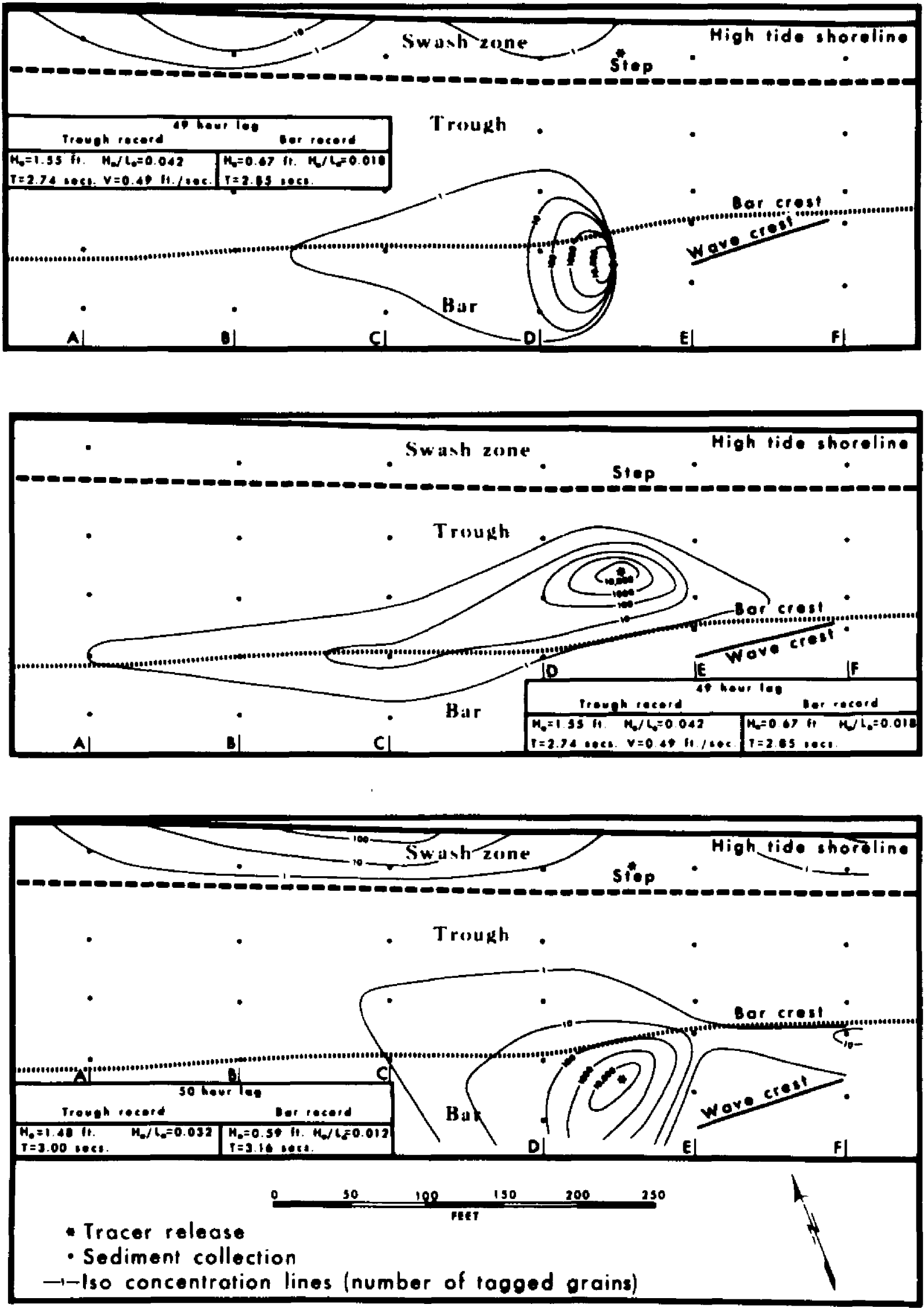

Figure 11 c. Tracer dispersion, experiment 2 . 


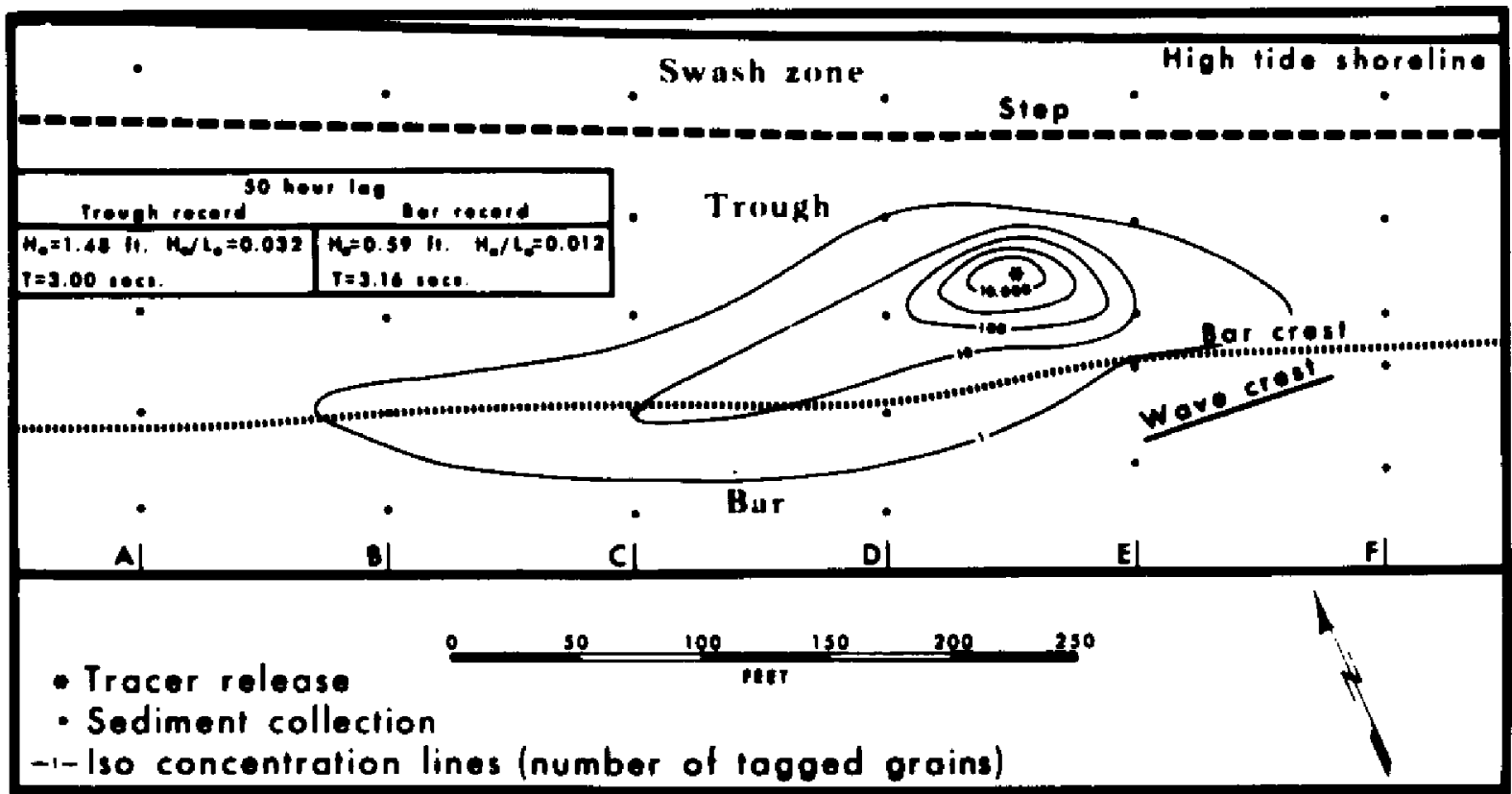

Figure 11 d. Tracer disperston, experiment 2 . 

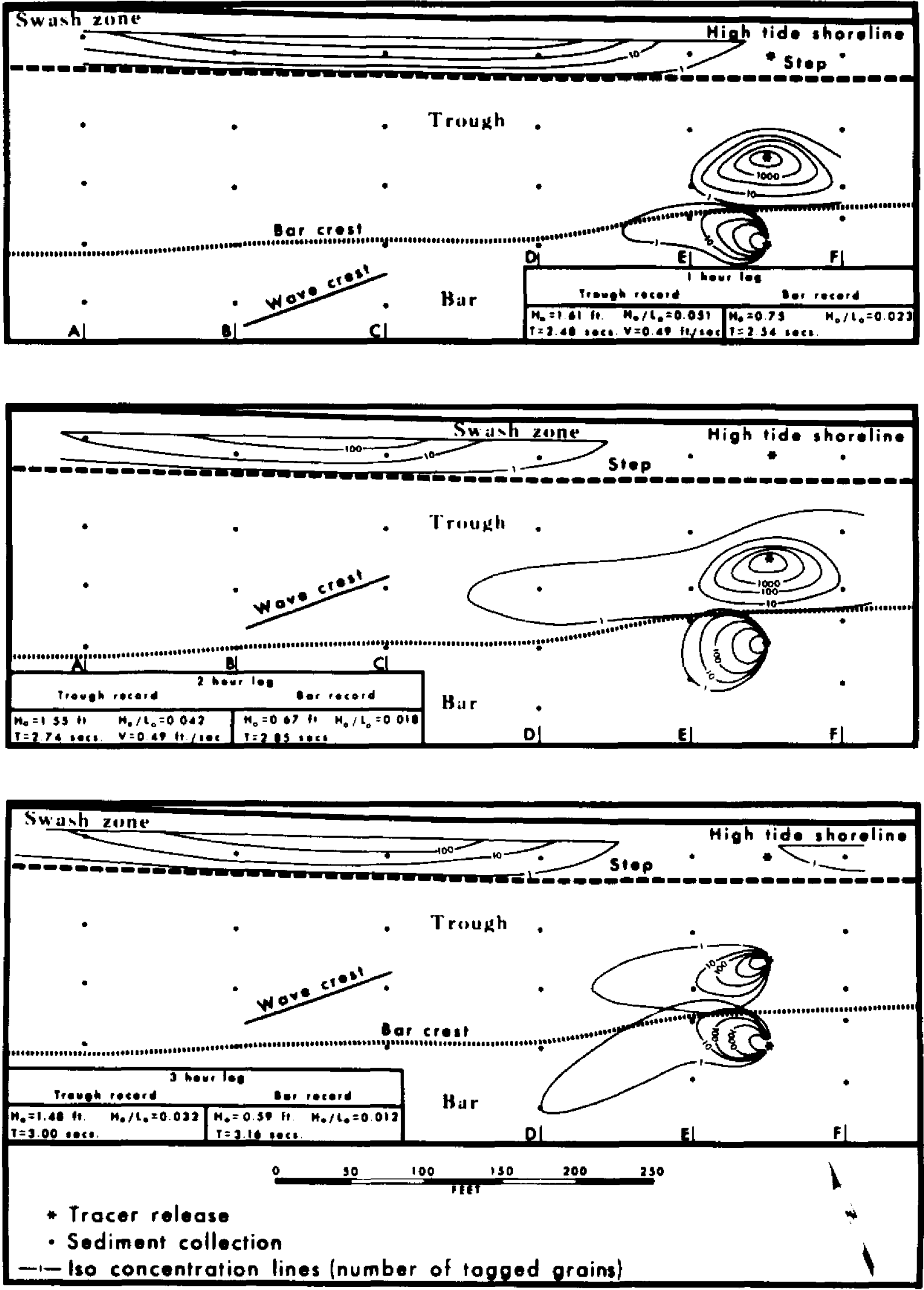

Figure 12. Tracer dispersion, experiment 3. 


\section{B IBLIOGRAPHY}

Boon, J. C., III, 1968, Trend surface analysis of sand tracer distributions on a carbonate beach, BImInI, B.W.I. Journ. Geol., v. 76 , no. 1 , pp. 71-87.

Crickmore, M. J. and G. H. Lean, 1962, The measurement of sand transport by means of radloactive tracers. Proc., Royal Soc., A, v. 266, PP. 402-421.

Davidsson, J., 1958, Investigations of sand movements using radioactive sand. Lund studies in geography, Ser. A, Physlcal Geography, 3, Sw. Kr., pp. 107-126.

Draper, L., 1966, The analysts and presentation of wave data--a plea for uniformity. Proc., 10th Conf. on Coastal Eng., Am. Soc. Civ11 Engineers, N.Y., v. 1, Part 1, PP. 1-11.

Evans, 0. F., 1939, Sorting and transportation of material in the swash and backwash. Journ. Sed. Pet., v. 9, no. 1, pp. 28-31.

Grant, U. S., 1943, Waves as a sand-transporting agent. Am. Journ. Sc1., v. 241 , no. 2, Pp. 117-123.

Harrison, W., and W. C. Krumbeln, 1964, Interactions of the beachocean-atmosphere system at Virginia Beach, Virginia. U.S. Army, C.E.R.C., Tech. Memo. No. 7, 102 pp.

Ingle, J. C., 1966, The movement of beach sand. Developments in Sedimentology, 5, Elsevier Publishing Co., Amsterdam, 221 pp.

Inman, D. L. and J. Filloux, 1960, Beach cycles related to tide and local wind wave reglme. Journ. Geol., v. 68, no. 2, PP. 225-231. 
Johnson, D. W., 1919, Shore processes and shoreline development.

New York (Hafner), facsimile edition, 1965, p. 584.

Johnson, J. W., 1949, Sand transport by 11ttoral currents. Proc. 5th Hydraulics Conf., Bulletin 34, State Univ. Iowa Studies in Englneering, Pp. 89-109.

King, C. A. M., 1959, Beaches and coasts. London (Edward Arnold), 403 pp.

Medvedev, V. C. and N. A. Albulatov, 1958, A study of sandshore dynamlcs using luminescent sand grains and an aerial tramway. Tr. Inst. Okeano1., Akad. Nauk. S.S.S.R., v. 28, pp. 37-55 (translated from Russtan by M. C. Blake), 23 pp.

Miller, R. L. and J. M. Zelgler, 1964, A study of sediment distribution In the zone of shoaling waves over complicated bottom topography. In (R. L. M1ller, ed.) Papers In marine geology, Shepard Commemorative Vol., 1964, Pp. 133-153.

Rector, R. L., 1954, Laboratory study of equilibrium profiles of beaches. U.S. Army Corps of Englneers, B.E.B. Tech. Memo. No. 41, $38 \mathrm{pp}$.

Sato, S., 1962, Sand movement at Fukue Coast in Atsumi Bay, Japan, and 1ts observation by radioactive glass sand. Coastal Eng. in Japan, v. 5, pp. 81-92.

Scott, T., 1954, Sand movement by waves. U.S. Army Corps of Engineers, B.E.B. Tech. Memo. No. 48, 37 Pp.

Shepard, F. P., 1950, Beach cycles in Southern California. U.S. Army Corps of Engineers, B.E.B. Tech. Memo. No. 20.

Shepard, F. P., 1963, Submarine geology. New York (Harper and Row), second edition, $557 \mathrm{pp}$. 
Shepard, F. P., K. O. Emery, and E. C. LaFond, 1941, RIp currents: a process of geological importance. Journ. Geol., v. 49, pp. 337369.

Sonu, C. J., J. M. McCloy, and D. S. McArthur, 1966, Longshore currents and nearshore topographtes. Proc. 10th Conf. on Coastal Eng., Am. Soc. C1v11 Englneers, N. Y., v. 1, part 2, pp. 525-549.

Sonu, C. J. and R. J. Russe11, 1966, Topographic changes In the surf zone profile. Proc. 10th Conf. on Coastal Eng., Am. Soc.

C1v11 Engineers, N. Y., v. 1, part 2, pp. 502-524.

Steel, R. G. D. and J. H. Torrie, 1960, Principles and procedures of statistics. New York (McGraw-H111), 481 pp .

Strahler, A. N., 1966, Tidal cycle of changes in an equilibrium beach, Sandy Hook, New Jersey. Journ. Geo1., v. 74, no. 3, pp. 247-268.

Wiegel, R. L., 1953, Waves, tides, currents and beaches: glossary of terms and list of standard symbols. Council on Wave Research, The Engineering Foundation, 113 pp.

Wright, F. F., 1962, The development and application of a fluorescent marking technique for tracing sand movements on beaches. Dept. of Geology, Columbia University, Tech. Rept. No. 2 of O.N.R., Geography Branch Project NR 388 057, Contract Nonr 266(68), 19 pp.

Yasso, W. E., 1966, Formulation and use of fluorescent tracer coatings in sediment transport studies. Sedimentology, v. 6, pp. 287-301. Zenkovich, V. P., 1967, Processes of coastal development. New York (Intersclence Publishers). Translated from Russian by D. G. Fry, edited by J. A. Steers, 738 pp. 


\section{V1ta}

David Samue1 McArthur was born at Nelson, New Zealand, on May 3, 1941. He recelved five years of secondary education at Nelson College, during which time School Certificate, Endorsed School Certificate, Higher School Certificate, and University Entrance diplomas were obtained. Proceeding to the University of Canterbury with the financial ald of a Post Primary Teacher's Studentsh1p, he was awarded a Bachelor of Science degree from the University of New Zealand after three years' study in geography, geology, pure mathematics, and biology. That was In 1962. Two additional years of study in geography, which included coastal research, qualifled him for a Master of Science degree with honors classification. This be recelved from the University of Canterbury in 1964.

During 1963 the writer attended Christchurch Teachers College as a full-time student, taking courses in education and teaching methods for geography and science subjects. The following year was spent teaching as a secondary assistant master at Culverden District High School in New Zealand. At the end of 1964 he was granted a Diploma in Teaching by the New Zealand Department of Education.

In January of 1965 he left New Zealand for Baton Rouge, LouisIana, to begin a doctoral program in the Department of Geography and Anthropology at Loulsiana State University. Transferral from a teaching assistantship with the department to a research assistantship with Coastal Studies Institute followed after a year's residence. Dissertation research was carrled out through the factilities and 
support of the Institute.

The writer is a member of the New Zealand Geographical Soclety, the Assoctation of American Geographers, and the American Geographical Socfety . 
EXAMINATION AND THESIS REPORT

Candidate: David Samuel MacArthur

Major Field: Geography

Title of Thesis: Sand Movement in Relation to Beach Topography

Approved:

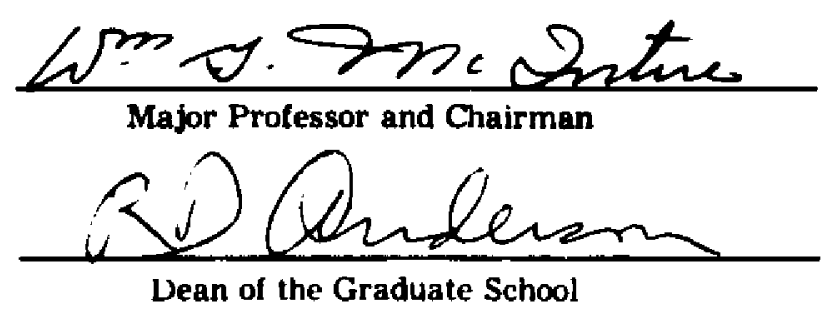

EXAMINING COMMITTEE:

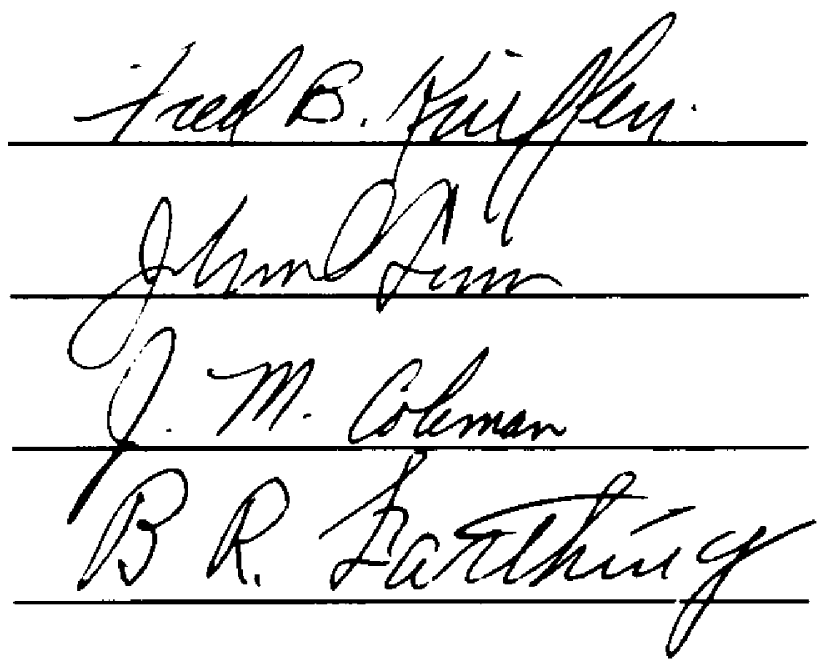

Date of Examination:

December 19,1968 